THE UNEASY CASE FOR THE PRIORITY OF SECURED CLAIMS IN BANKRUPTCY: FURTHER THOUGHTS AND A REPLY TO CRITICS

Lucian Arye Bebchuk Jesse Fried

Working Paper 6472 


\title{
THE UNEASY CASE FOR THE PRIORITY OF SECURED CLAIMS IN BANKRUPTCY: FURTHER THOUGHTS AND A REPLY TO CRITICS
}

\section{Lucian Arye Bebchuk \\ Jesse Fried}

Working Paper 6472

http://www.nber.org/papers/w6472

\author{
NATIONAL BUREAU OF ECONOMIC RESEARCH \\ 1050 Massachusetts Avenue \\ Cambridge, MA 02138 \\ March 1998
}

Any opinions expressed are those of the authors and not those of the National Bureau of Economic Research.

(C) 1998 by Lucian Arye Bebchuk and Jesse Fried. All rights reserved. Short sections of text, not to exceed two paragraphs, may be quoted without explicit permission provided that full credit, including $(\odot$ notice, is given to the source. 
The Uneasy Case for the Priority of Secured Claims

in Bankruptcy: Further Thoughts and a Reply to Critics

Lucian Arye Bebchuk and Jesse Fried

NBER Working Paper No. 6472

March 1998

JEL Nos. G33, K22

\begin{abstract}
In an earlier article, "The Uneasy Case for the Priority of Secured Claims in Bankruptcy," 105 Yale Law Journal 857 (1996), we suggested that the case for a full priority of secured claims in bankruptcy is an uneasy one. In this paper, we address various reactions and objections to our analysis that have been offered by subsequent work. We also further develop some of the main elements of the analysis in our earlier article - with respect to both our analysis of the comparative merits of full and partial priority and our analysis of how a partial priority regime could be implemented. The analysis confirms our earlier conclusion that the case for a full priority of secured claims in bankruptcy is an uneasy one.
\end{abstract}

Lucian Arye Bebchuk

Harvard Law School

1557 Massachusetts Avenue

Cambridge, MA 02138

and NBER

bebchuk@law.harvard.edu
Jesse Fried

School of Law (Boalt Hall - 343)

University of California at Berkeley

Berkeley, CA 94720

friedj@uclink4.berkeley.edu 


\section{TABLE OF CONTENTS}

INTRODUCTION.

I. Preliminary Observations and Initial Intuitions

A. Full Priority Is Inconsistent with the General Principle Against Nonconsensual Subordination.

B. Is Full Priority Required by Freedom of Contract Principles?.................

C. Is Full Priority Required by Principles of Property Law?....................

D. What Lessons Can We Learn from the World Around Us?......................

E. Considering the Issue of Priority with an Open Mind........................

II. ON THE EXCESSIVE USE OF SECURTY INTERESTS UNDER Full PrIORITY........... 12

A. The Concept of "Nonadjusting" Creditors.................................

1. Involuntary Creditors................................................

2. Government Tax and Regulatory Claims................................ 17

3. Voluntary Creditors with Small Claims............................... 18

4. Prior Voluntary Creditors............................................... 20

B. Nonadjusting Creditors and the Use of Inefficient Security Interests........... 23

1. The Problem............................................................ 20

2. Excessive Use Can Occur Without Involuntary Creditors................... 26

3. Can Disclosure by Borrowers Eliminate the Problem of Excessive Use?.. 27

C. Empirical Evidence That Security Interests Are Often Inefficient.............. 28

1. The Persistence of Unsecured Debt....................................... 28

2. Negative Pledge Clauses................................................ 30

D. Who is Hurt by the Use of Security Interests Under Full Priority?.......... 32

III. ON THE Other EfFiciency COSts of Full Priority.......................... 33

A. Reduced Monitoring by Secured Lenders Under Full Priority................. 33

1. Reduced Use of Covenants................................................ 34

2. Reduction in Monitoring..................................................

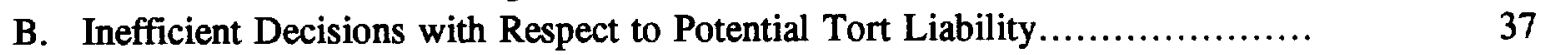

C. Funding of Marginal Activities......................................... 38

IV. ON THE Design of Partial-Priority Rules................................... 39

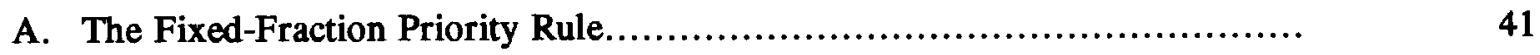

B. The Adjustable-Priority Rule............................................. 43

C. A Consensual Priority Rule............................................... 44

D. Why Not Partial Priority Outside of Bankruptcy?........................... 45 
V. On the Cost and Availability of Financing Under Partial Priority

A. Some Preliminary Points.................................................. 47

1. The Availability of Secured Credit Under Partial Priority................... 47

2. The Aggregate Cost of Credit Under Partial Priority....................... 49

B. The Financing of Good and Bad Projects................................. 50

1. The Question................................................................. $\quad 50$

2. The Effect of Partial Priority on the Financing of Good Projects............. 50

3. The Effect of Partial Priority on the Financing of Bad Projects............... 51

4. Assessing the Overall Effect of Partial Priority on Financing................. 52

C. The Effect of Partial Priority on the Financing of Post-Bankruptcy Projects..... 52

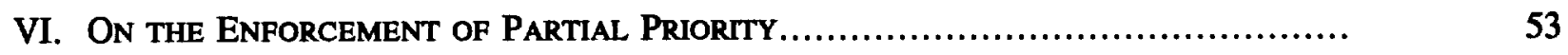

A. The Tension Between the Circumvention and Credit Availability Arguments against Partial Priority....................................................... 53

B. Circumvention Through Alternative Forms of Financing..................... 54

1. The Severity of the General Problem........................................ 54

2. The Use of Lease Arrangements........................................... 55

3. The Use of Subsidiaries.................................................. 57

4. "Special Purpose" or "Bankruptcy Remote" Vehicles....................... 58

C. Liquidation of Collateral Outside of Bankruptcy............................... 59

1. Firms That Liquidate Outside of Bankruptcy............................. 59

2. Firms That Give Secured Creditor Their Collateral Prior to Bankruptcy....... 60

VII. A Note on the Current Controversies Over Article $9 \ldots \ldots \ldots \ldots \ldots \ldots \ldots \ldots \ldots \ldots$

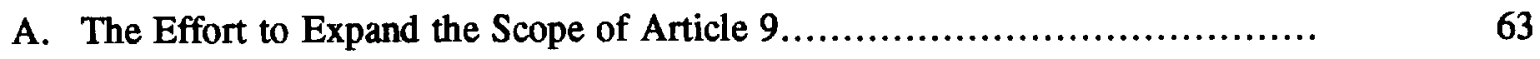

B. The "Carve-Out" Proposal................................................ 64

ConCLUSION................................................................... $\quad 65$ 


\section{INTRODUCTION}

A longstanding and basic principle of U.S. bankruptcy law is that a secured creditor is entitled to receive the entire amount of its secured claim-the portion of its bankruptcy claim that is backed by collateral-before any unsecured claims are paid. ${ }^{1}$ This principle of full priority ${ }^{2}$ is generally reflected in the provisions of the U.S. Bankruptcy Code, ${ }^{3}$ although, as is widely recognized, there are number of rules, doctrines, and practices that have the effect of eroding the priority of secured claims in bankruptcy. ${ }^{4}$ Until relatively recently, there has been a general consensus among economists and legal scholars that secured claims should be given full priority in bankruptcy because full priority promotes desirable contracting between borrowers and their creditors. ${ }^{5}$ As a result, the rules, doctrines, and practices that cause deviations

1 We follow the U.S. Bankruptcy Code in using the term "secured claim" to refer to the portion of a creditor's bankruptcy claim that is fully backed by collateral, and the term "unsecured claim" to refer to the portion of a creditor's claim that is not backed by any collateral. 11 U.S.C. $\S 506$ (a) (1994).

2 The Article uses the term "full priority" to mean that, in bankruptcy, a secured creditor has $100 \%$ priority in its collateral over the rights of unsecured creditors. The term "unsecured creditors" refers to unsecured creditors that have not explicitly consented to subordination.

3 The principle that secured claims are to be paid in full before any unsecured claims are paid is embodied in the "adequate protection" provisions of the U.S. Bankruptcy Code. 11 U.S.C. \$\$ 362-364 (1994). The principle of full priority is also reflected in the bankruptcy systems of many other countries. See generally DENNIS CAMPBELL, INTERNATIONAL CORPORATE INSOLVENCY LAW (1992) (surveying national insolvency and bankruptcy laws of more than twenty countries). However, an increasing number of foreign bankruptcy systems provide secured creditors with only partial priority in their collateral over the claims of unsecured creditors. See infra note 38 and accompanying text.

4 See infra Section II.D.

5 Those writing from an economic perspective have generally operated under the premise that full priority yields efficiency benefits and should be respected in bankruptcy. Much of the scholarly work has focused on what those efficiency benefits might be. Contributions to this literature include Barry E. Adler, An Equity-Agency Solution to the Bankruptcy-Priority Puzzle, 22 J. Legal. STUD. 73 (1993); F.H. Buckley, The Bankruptcy Priority Puzzle, 72 VA. L. REV. 1393 (1986); David Gray Carlson, On the Efficiency of Secured Lending, 80 VA. L. REv. 2179 (1994); Jochen Drukarczyk, Secured Debt, Bankruptcy, and the Creditors' Bargain Model, 11 INT'L REV. L. \& ECON. 203 (1991); Thomas H. Jackson \& Anthony T. Kronman, Secured Financing and Priority Among Creditors, 88 YALE L.J. 1143 (1979); Alex M. Johnson, Jr., Adding Another Piece to the Financing Puzzle: The Role of Real Property Secured Debt, 24 LoY. L.A. L. REv. 335 (1991); Hideki Kanda \& Saul Levmore, Explaining Creditor Priorities, 80 VA. L. REv. 2103 (1994); Saul Levmore, Monitors and Freeriders in Commercial and Corporate Settings, 92 YALE L.J. 49 (1982); Randal C. Picker, Security Interests, Misbehavior, and Common Pools, 59 U. CHI. L. Rev. 645 (1992); Alan Schwartz, A Theory of Loan Priorities, 18 J. LEGAL STUD. 209 (1989) [hereinafter Schwartz (1989)]; Alan Schwartz, Security Interests and Bankruptcy Priorities: A Review of Current Theories, 10 J. Legal STUD. 1 (1981) [hereinafter Schwartz (1981)]; Alan Schwartz, Taking the Analysis of Security Seriously, 80 VA. L. REV. 2073 (1994) Thereinafter 
from full priority in bankruptcy have come under considerable criticism. ${ }^{6}$

In a paper published last year in the Yale Law Journal entitled The Uneasy Case for the Priority of Secured Claims in Bankruptcy ${ }^{7}$ [hereinafter The Uneasy Case], we presented a detailed analysis of the economic costs that arise from according full priority to secured claims in bankruptcy. ${ }^{8}$ One of the main contributions of the paper was to show that full priority could give rise to inefficient contracting ${ }^{9}$ between a borrower and its creditors, and to several types of efficiency costs even in a world where all of the borrower's creditors are voluntary and sophisticated. We also presented two partial priority rules that could reduce the inefficiencies we identified (one of which could, in

Schwartz (1994)]; Alan Schwartz, The Continuing Puzzle of Secured Debt, 37 Vand. L. ReV. 1051 (1984) [hereinafter Schwartz (1984)]; Robert E. Scott, A Relational Theory of Secured Financing, 86 COLUM. L. REv. 901 (1986); Paul M. Shupack, Solving the Puzzle of Secured Transactions, 41 RUTGERS L. REV. 1067 (1989); Clifford W. Smith \& Jerold B. Warner, Bankruptcy, Secured Debt, and Optimal Capital Structure: Comment, 34 J. Fin. 247 (1979); René M. Stulz \& Herb Johnson, An Analysis of Secured Debt, 14 J. Fin. EcoN. 501 (1985); George G. Triantis, Secured Debt Under Conditions of Imperfect Information, 21 J. LEGAL STUD. 225 (1992); Lawrence A. Weiss, Bankruptcy Resolution: Direct Costs and Violation of Priority of Claims, 27 J. Fin. Econ. 285 (1990); James J. White, Efficiency Justifications for Personal Property Security, 37 VAND. L. REV. 473 (1984). The view that full priority is socially desirable is shared by many writings outside of the law and economics literature. See, e.g., Steven L. Harris \& Charles W. Mooney, Jr., A Property-Based Theory of Security Interests: Taking Debtors' Choices Seriously, 80 VA. L. REV. 2021 (1994) (claiming that full priority is required by freedom of contract and property rights principles); Homer Kripke, Law and Economics: Measuring the Economic Efficiency of Commercial Law in a Vacuum of Fact, 133 U. PA. L. REV. 929 (1985) (arguing that full priority increases supply of credit); James J. White, Work and Play in Revising Article 9, $80 \mathrm{VA}_{\mathrm{A}}$ L. REV. 2089 (1994) (asserting that widespread and longstanding use of security interests demonstrates their social desirability).

6 See, e.g., Jeffrey S. Turner, The Broad Scope of Revised Article 9 is Justified, ConsumER FIN. L.Q. REP. 328 (1996); Weiss, supra note 5, at 299-300 (discussing effects of violation of priority); James J. White, The Recent Erosion of the Secured Creditor's Rights Through Cases, Rules and Statutory Changes in Bankruptcy Law, 53 Miss. L.J. 384 (1983).

7 Lucian Arye Bebchuk \& Jesse M. Fried, The Uneasy Case for the Priority of Secured Claims in Bankruptcy, 105 YALE L.J. 857 (1996).

8 For a more informal discussion of the costs of full priority, see Jesse M. Fried, Taking the Economic Costs of Priority Seriously (forthcoming ConsUMER FIN. L.Q. REP. 1997).

9 In The Uneasy Case and this Article, we use the standard Kaldor-Hicks definition of economic efficiency. Bebchuk \& Fried, supra note 7, at 863-64; infra. Under this definition, an arrangement, activity, or rule is efficient to the extent that it maximizes total social wealth (even if the arrangement, activity, or rule reduces the wealth of some parties). See Jules L. Coleman, Efficiency, Utility, and Wealth Maximization, 8 HofsTrA L. REV. 509, 513-14 (1980). An "efficiency benefit" increases total social wealth while an "efficiency cost" decreases total social wealth. 
principle, eliminate them). ${ }^{10}$ We suggested that the two rules of partial priority be considered as possible alternatives to the principle of full priority and the ad hoc system of partial-priority that currently governs the treatment of secured claims in bankruptcy.

In writing this paper we have two aims. First, our analysis in The Uneasy Case has attracted various reactions from the contributors to this Symposium and others, ${ }^{11}$ and we wish to address the objections that have been raised. Second, we wish in the paper to develop further some of the main elements of the analysis in The Uneasy Case.

The four main arguments that have been raised against our analysis-and to which we respond in this paper-appear to be as follows: (1) that full priority is required by fundamental principles of contract and property law (and therefore that a rule of partial priority would be inconsistent with these principles); (2) that the economic costs of full priority are lower than we suggest; (3) that even if the economic costs of full priority are high, the costs associated with a partial priority rule, such as the ones we consider, would be even higher (in particular, a partial priority rule would reduce financing for desirable activities, resulting in an economic cost that would far outweigh any benefits); and (4) that parties could circumvent the partial priority rules we put forward, and, therefore, that adoption of these rules would have little beneficial effect. Critics suggest two ways in which borrowers and their lenders could circumvent a rule of partial priority in bankruptcy: (1) through the use of arrangements that have the same effect as a security interest under full priority but which are beyond the reach of a partial rule; and (2) by the secured creditor recovering its collateral outside of, or prior to, bankruptcy.

The analysis of this paper is organized as follows. We begin in Part II by explaining why the issue of priority should be considered with an open mind. To that end, Part II first offers a set of intuitions regarding why, in contrast to views expressed by our critics, full priority is not required by (and in some cases is inconsistent with) important principles of contract, property, and insolvency law. Part II then discusses two important implications of the fact that the current system is one of de facto partial priority. The first is that a formal rule of partial priority would not necessarily be a radical change. The second is that those who defend full priority by arguing that the existing system works well are in fact providing evidence in support of partial priority.

10 Bebchuk \& Fried, supra note 7, at $904-11$.

11 See, e.g., Steven L. Harris \& Charles W. Mooney, Jr., Measuring the Social Costs and Benefits and Identifying the Victims of Subordinating Security Interests in Bankruptcy, 82 CORNELL L. REV. [101, 105-07, 115-17, 122] (1997); Lynn M. LoPucki, Should the Secured Credit Carve Out Apply Only in Bankruptcy? A Systems/Strategic Analsyis, 82 CoRnell L. REV. [101, 114-30] (1997); Ronald J. Mann, The First Shall Be Last: A Contextual Argument for Abandoning Temporal Rules of Lien Priority, 75 TEX. L. REv. 11, 45-49 (1996). Steven L. Schwarcz is currently in the process of writing an extensive critique of The Uneasy Case. Steven L. Schwarcz, The Easy Case for the Priority of Secured Claims in Bankruptcy, 47 DuKE L.J. ___ (forthcoming Dec. 1997). Because Schwarcz's paper will be finalized only after publication of this Symposium issue, we must defer a full response to some future occasion. 
Parts III and IV further develop our claim that full priority can produce significant efficiency costs and respond in detail to criticisms of this claim. Part III focuses on the excessive use of security interests that results from full priority, and Part IV describes the other types of efficiency costs associated with full priority.

Part V describes three partial priority rules that could be considered as alternatives to full priority and the current system of de facto partial priority. In addition to the two partial priority rules that we considered in The Uneasy Case, we put forward for consideration, a third partial priority rule: giving a secured creditor priority in its collateral in bankruptcy only over the claims of unsecured creditors that have explicitly consented to be subordinated.

After describing how priority might be implemented, we turn to the third and fourth objections that critics of our analysis have raised. Part VI addresses the objection that partial priority rules such as the ones we present would reduce the availability of financing for desirable investments. Part VII addresses the objection that creditors can circumvent a partial priority rule (a) by the use of alternative arrangements which operate like security interests under full priority but which are beyond the reach of the rule; and (b) by secured creditors recovering their collateral outside of, or prior to, bankruptcy.

Finally, before concluding, Part VIII remarks on how our analysis relates to the current controversies over the revision of Article 9 and the "carve-out" proposal.

\section{PRELIMINARY OBSERVATIONS AND INITIAL INTUITIONS}

There is a commonly held view, expressed by some participants at the Symposium, that full priority is required by freedom of contract and property rights considerations. Indeed, many people think of a "security interest" as a device that, by definition, gives the secured lender full priority in the collateral over the claims of all third parties, including unsecured creditors. ${ }^{13}$ To people accustomed to this way of thinking, the notion of a rule that gives secured creditors only partial priority over the claims of unsecured creditors in bankruptcy may initially appear puzzling. Therefore, we wish to start our analysis by offering a set of intuitive reasons why the issue of priority should be approached with an open mind. ${ }^{14}$

12 See Memorandum from Elizabeth Warren to the Council of the American Law Institute (Apr. 25, 1996) (on file with authors) (proposing Article 9 Set Aside for Unsecured Creditors).

13 See William J. Woodward, Jr., The Realist and Secured Credit: Grant Gilmore, Common Law Courts, and the Article 9 Reform Process, 82 CORNELL L. REV. [101, 101] (1997) (observing that "[t]he priority of secured debt is one of its central, defining features").

14 The discussion draws on, and further develops, material in Bebchuk \& Fried, supra note 7, at 86872 and 931-34. 
A "security interest" is simply a legal arrangement that gives the borrower, the lender, and third parties certain rights that are specified by law. And although historically those rights in the United States have generally included the secured lender's right to full priority in the underlying collateral, we explain below that there is no legal principle that requires that secured lenders have full priority over unsecured creditors' claims in bankruptcy. Nor is full priority required by economic considerations: in practice, secured creditors in the United States already do not have full priority in bankruptcy, and many other countries have adopted rules that explicitly give secured creditors only partial priority in bankruptcy. ${ }^{15}$ Indeed, the next two Parts explain why it might be economically desirable to deny secured creditors full priority in their collateral in bankruptcy.

Section A explains that, notwithstanding its long history, full priority is actually inconsistent with an important general principle of commercial law: that a borrower may not subordinate one creditor's claim to that of another without the consent of the subordinated creditor. Section B explains why full priority is not required by freedom of contract. Section $C$ explains in turn why full priority is not required by property rights considerations. Section $D$ points out that our system is already one of de facto partial priority, which has two important implications. First, adopting a formal rule of partial priority would not necessarily be such a radical change. Second, claims that the existing system works well actually support the case for partial priority, not full priority. Section E summarizes the arguments for why the issue of priority should be approached with an open mind.

A. Full Priority is Inconsistent with the General Principle Against Nonconsensual Subordination

Because most firms entering bankruptcy are insolvent, there is generally insufficient value to pay every claim in full. An important purpose of the bankruptcy system is to determine the proper distribution of that value. Under the bankruptcy systems of the United States and many other countries, pro rata sharing is the general rule. ${ }^{16}$ That is, any assets that remain after secured claims are paid in full are divided pro rata among those with unsecured claims. ${ }^{17}$ In the absence of secured claims, all of the assets of the bankruptcy estate are distributed on a pro rata basis.

A fundamental principle of bankruptcy law is that-once a statutorily created

15 See infra note 38 and accompanying text.

16 See generally Campbell, supra note 3 (surveying bankruptcy systems of a number of countries). For another possible method of allocating bankruptcy value, see Schwartz (1989), supra note 5, at 210-12 (suggesting that the initial lenders should have priority over later creditors).

17 Under U.S. bankruptcy law and the laws of most other countries, certain preferred classes of unsecured claims (the claims of certain government units, certain wage claims, inter alia) are paid in full before other "ordinary" or "general" unsecured creditors. See 11 U.S.C. $\$ 507$ (1994). For ease of exposition, we assume throughout that all unsecured creditors are treated equally in bankruptcy. This assumption is not critical to any of the analysis. 
scheme for allocating a bankrupt debtor's assets among its creditors is in place, the borrower may not circumvent that scheme by transferring one creditor's bankruptcy allocation to another party without the former's consent. That is, a borrower may not favor one creditor at the expense of another. For example, unsecured creditor $C 1$ may not contract with the borrower for its claim to have priority in bankruptcy over that of another unsecured creditor C2. ${ }^{18}$ The law also does not allow a borrower to contract with unsecured creditor $\mathrm{Cl}$ to provide it with preferential payments on the eve of bankruptcy. ${ }^{19}$ Were the borrower to contract with creditor $\mathrm{Cl}$ for priority over creditor $\mathrm{C2}$ in bankruptcy, or for preferential payments outside of bankruptcy, the contract would be completely disregarded if the borrower ever entered bankruptcy. ${ }^{20}$ Indeed, the only way for creditor $\mathrm{Cl}$ to subordinate creditor $C 2$ 's claim is by negotiating a subordination agreement with creditor $C 2$ under which creditor $C 2$ promises to pay creditor $C 1$ as much of what creditor $C 2$ receives in bankruptcy as is necessary to make creditor $C l$ whole. Such arrangements are often observed. Presumably, the creditor consenting to subordination receives a higher interest rate from the borrower or compensation directly from the subordinating creditor.

There is, however, one exception to the general principle that subordination must be consensual: a borrower may use a security interest, under the rule of full priority, to subordinate creditor $C 2$ 's claim to creditor $C 1$ 's claim. Thus, while a borrower may not subordinate the claim of unsecured creditor $C 2$ to that of creditor $C 1$ without creditor $C 2$ 's consent, that borrower can achieve the exact same result under the rule of full priority by giving creditor $\mathrm{Cl}$ a security interest. Given the general rule that the debtor may not give creditor Cl's claim priority over that of a single other creditor, it would appear peculiar that by complying with a few mechanical procedures, the debtor and creditor $\mathrm{Cl}$ can arrange to give creditor Cl's claim priority over the claims of all unsecured creditors without obtaining those unsecured creditors' consent. One could argue that, although subordination through the use of a security interest does deviate from the general norm that explicit consent is required, unsecured creditors implicitly consent to subordination. The following discussion identifies two possible implicit consent arguments and explains why neither has much force.

The first implicit consent argument in defense of full priority is that there is implicit consent to the creation of each security interest. ${ }^{21}$ In most cases, a security interest created by the debtor gives creditor $C l$ 's claim full priority over that of creditor $C 2$ only if creditor $C 1$ perfects the security interest by recording it in a public registry. Because the

18 See James Steven Rogers, The Impairment of Secured Creditors' Rights in Reorganization: A Study of the Relationship Between the Fifth Amendment and the Bankruptcy Clause, 96 HARV. L. REv. 973, 994-95 (1983).

19 See 11 U.S.C. $\$ 547$ (1994).

20 See Rogers, supra note 13, at 994-95. Similarly, the law does not permit a firm to sell options on its bankruptcy value to noncreditors. See Buckley, supra note 5, at 1456 \& n.139.

21 See Bebchuk \& Fried, supra note 7, at 869-70. 
security interest is publicly registered, creditors whose bankruptcy allocations have been reduced by the creation of the security interest are able to adjust their terms or can refuse to lend in the first instance. Consequently, by entering into a transaction with the borrower, these creditors implicitly consent to having their fractional share of the borrower's bankruptcy assets reduced.

However, a substantial number of creditors can neither consent nor be assumed to implicitly agree, let alone know about, the creation of every security interest that subordinates their claims. ${ }^{22}$ Tort creditors, for example, would be unlikely to implicitly agree to have their claims subordinated by a security interest giving the secured lender full priority. ${ }^{23}$ Indeed, under current law, a security interest could be used to subordinate the claim of an unsecured creditor that had explicitly refused to subordinate its claim. Consider a borrower's agreement with creditor $C 2$ that creditor C2's claim would not be subordinated to that of any other creditor. Borrowers and creditors widely use such agreements. ${ }^{24}$ However, under full priority, a security interest created by the borrower in violation of the borrower's nonsubordination agreement with creditor $C 2$ will give the secured creditor priority in the collateral over the claim of creditor $C 2 .{ }^{25}$ Thus, in the case of any given security interest, there is not necessarily implicit consent.

The second possible implicit consent argument is that all unsecured creditors are better off if the borrower has the ability to subordinate their claims without obtaining their explicit consent, and therefore, all unsecured creditors would prefer a nule of full priority to one in which such consent would be required to create a security interest subordinating their claims. If so, full priority would efficiently provide a subordination regime to which all unsecured creditors would agree (at least ex ante). But for this implicit consent argument to succeed, those advancing it must show that all unsecured creditors would be better off under full priority than under any feasible alternative. The analysis we offer in the next two Parts suggests that while many unsecured creditors would be no worse off under full priority than under a rule of partial priority, many unsecured creditors would be worse off. These unsecured creditors could not be presumed to implicitly consent to full priority.

Finally, even if one could show that there is implicit consent to subordination, the rule of full priority is still inconsistent with the general requirement that consent to

22 Id. at 869.

23 We are not claiming that a creditor with a tort claim would never benefit from the creation of a security interest subordinating its claim. In certain cases, the granting of a security interest giving a lender full priority could make a tort creditor (as well as other nonadjusting unsecured creditors) better off. See infra Part III.B.1.

24 See infra Part III.C.2.

2s See Equitable Trust Co. v. Imbesi, 412 A.2d 96 (Md. 1980) (holding that mortgagee had priority in property encumbered by borrower in violation of covenant); see also infra Part III.A.4 (discussing the uses of negative pledge covenants). 
subordination be explicit. Thus, those in favor of full priority must explain why subordination through the use of a security interest under full priority should not, like all other means of subordination, require the explicit consent of the subordinated party.

B. Is Full Priority Required by Freedom of Contract Principles?

Many share the sentiment, which was also expressed during the Symposium, that freedom of contract principles require a rule of full priority ${ }^{26}$ To illustrate this view, suppose that creditor $\mathrm{Cl}$ offers borrower a choice between (1) an unsecured loan to borrower in exchange for interest payments totalling $\$ 15$ (plus repayment of principal) and (2) a secured loan in exchange for interest payments of only $\$ 10$ (plus repayment of principal) that, if the borrower becomes insolvent, gives creditor $\mathrm{Cl}$ a larger fraction of the borrower's assets (and creditor $C 2$, borrower's other creditor, a smaller fraction). The freedom of contract argument asserts that borrower and creditor $\mathrm{Cl}$ should be free to choose either arrangement (1) or arrangement (2).

In general, if an arrangement would have no detrimental effect on third parties, freedom of contract principles would suggest permitting borrower and creditor $C 1$ to enter into the arrangement if they so choose. ${ }^{27}$ However, freedom of contract arguments are not applicable when the arrangement contemplated by borrower and creditor $C 1$ is at the expense of another party. In this case, since arrangement (2) is at the expense of creditor $C 2$, freedom of contract does not require that borrower and creditor $C l$ be permitted to enter that arrangement. ${ }^{28}$

To be sure, it might be argued that arrangement (2) only appears to be at the expense of creditor $C 2$. According to this argument, while arrangement (2) reduces creditor C2's fractional share of the borrower's bankruptcy assets ex post, relative to arrangement (1), arrangement (2) could actually make creditor $C 2$ better off than arrangement (1) ex ante by lowering the borrower's interest burden, thereby reducing the probability that the borrower will go bankrupt in the first instance. ${ }^{29}$ But the fact that arrangement (2) could, in theory, benefit creditor $C 2$ ex ante (relative to arrangement (1)) does not mean that freedom of contracts require that the borrower and creditor $C I$ be permitted to enter into that arrangement. To see why this is the case, consider two other arrangements that have the

26 See Harris \& Mooney, supra note 5, at 2049-51. Jeff Turner has also forcefully made this argument. Turner, supra note 6, at 329-31.

${ }^{27}$ Interestingly, Article 9 itself places restrictions on the types of arrangements that borrowers and lenders can enter into, even if no other parties are involved. See, e.g., U.C.C. \$ 9-502(2) (1994) (requiring secured lender to return surplus from sale to borrower, notwithstanding an agreement to the contrary).

28 Cf. Schwartz (1994), supra note 5, at 2082 (stating that "society commonly does and should respect voluntary transactions less" when such transactions may harm third parties).

29 This point is discussed further infra Part III.B.1. 
same ex ante and ex post effects on creditor $C 2$ as arrangement (2) but which are legally unenforceable.

First, suppose that creditor $C 1$ offers the borrower an unsecured loan under the same terms as arrangement (1) except that borrower need pay only $\$ 10$ in interest payments if it accepts the following provision: should the borrower go bankrupt, creditor $C l$ would have an option to buy its bankruptcy assets up to the value of the balance on the loan, at a strike price of $\$ 0$. Should the option be exercised, it would be at the expense of creditor $C 2$. Most people would agree that freedom of contract does not require observation of such a provision, and in fact, the law does not permit such an arrangement. ${ }^{30}$

Second, suppose that creditor $C 1$ offers the borrower an unsecured loan under the same terms as arrangement (1) except that the borrower need pay only $\$ 10$ in interest payments if the borrower agrees that should it file for bankruptcy it must first pay creditor $C I$ in full, effectively reducing the pro rata amount available to creditor $C 2$. Again, most people would agree that freedom of contract does not require the law to enforce such an arrangement, and in fact, such an arrangement is legally unenforceable. ${ }^{31}$

It is easy to see that the option and preference arrangements have the same ex ante effect on creditor $C 2$ as the creation of a security interest under full priority. Each of the arrangements could benefit creditor $C 2$ ex ante relative to an ordinary unsecured loan by reducing the probability of the borrower's bankruptcy. But we do not consider the option and preference arrangements required by freedom of contract principles. If these arrangements are not mandated by freedom of contract, then freedom of contract does not require that the borrower and creditor $C 1$ be permitted to enter into an almost identical arrangement through the creation of a security interest giving creditor $C l$ full priority in the borrower's bankruptcy assets.

C. Is Full Priority Required by Principles of Property Law?

Two types of property-rights arguments have been raised, in the discussion during the Symposium, in favor of full priority, and against partial priority. One focuses on the secured lender's property rights and the other focuses on the borrower's property rights.

The lender-based argument is that a partial priority rule would take from the secured creditor something for which it paid. However, as the lender-based argument carries no weight if the partial priority rule under consideration applies only to security interests created after its adoption. In this case, the secured creditors will enter into the arrangement knowing that they will receive partial priority, and partial priority will not defeat their

$30 C f$. Buckley, supra note 5, at $1456-60$ (discussing prohibition on issuance of bankruptcy rights to noncreditors and shareholders in particular).

$31 \quad$ See 11 U.S.C. $\$ 547$ (1994). 
expectations. $^{32}$

The borrower-based argument is that the borrower has the right to alienate its interests in its property in any way it sees fit. ${ }^{33}$ However, in granting a security interest in collateral under the rule of full priority, the borrower is alienating an interest not only in its own property, but also in the property of the bankruptcy estate, which the law considers to belong to the borrower's creditors as a group (and not to the borrower). Because the law does not permit a borrower to otherwise transfer or allocate its insolvency assets to third parties or to prefer certain creditors, the law is not required to permit the borrower to do so through the use of a security interest giving the secured creditor full priority. Of course, one is free to take the position that the assets of the bankruptcy estate belong to the debtor and that the debtor should have the right to allocate them however it likes. But this would imply that fraudulent conveyance law, preference law, and the rule of mandatory pro rata sharing all impediments to the exercise of this right and shall be eliminated.

D. What Lessons Can We Learn from the World Around Us?

In the Symposium and elsewhere, Steve Harris and others have argued that a partial priority rule would require radically changing a system that in their estimation works well. ${ }^{34}$ One implication of this argument is that the adoption of a partial priority rule is unlikely to offer much improvement while creating a significant degree of risk. Another argument is that advocates of a partial priority nule bear the burden of proof in this debate. ${ }^{35}$

To begin, participants on both sides of the priority debate recognize that we are already operating under a system of de facto partial priority. ${ }^{36}$ In particular, there are a number of doctrines, practices, and rules that tend to erode secured creditors' priority in

32 For a more detailed discussion of this argument, see Bebchuk \& Fried, supra note 7, at 931-32; see also Kenneth N. Klee, Barbarians at the Trough: Riposte in Defense of the Warren Carve-Out Proposal, 82 CORNELL L. REv. [101, 112-13] (1997) (arguing that prospective application of a partial priority would not constitute an illegal taking); Rogers, supra note 18, at 986-87 (same).

33 See Harris \& Mooney, supra note 5, at 2047-53; Turner, supra note 6, at 328-29.

34 See, e.g., Harris \& Mooney, supra note 5.

35 See, e.g., Turner, supra note 6, at 329.

36 See, e.g., Douglas G. Baird \& Thomas H. Jackson, Corporate Reorganizations and the Treatment of Diverse Ownership Interests: A Comment on Adequate Protection of Secured Creditors in Bankruptcy, 51 U. CHI. L. Rev. 97, 112-14 (1984); Lawrence A. Weiss, The Bankruptcy Code and Violations of Absolute Priority, 4 J. APPL. CORP. FIN. 71 (1991); White, supra note 6, at 392-94; Woodward, supra note 13 , at [107-11]. 
bankruptcy, ${ }^{37}$ some of which we briefly discussed in The Uneasy Case.$^{38}$ For example, because a secured creditor usually cannot seize its collateral once a firm has filed for bankruptcy, the creditor is subject to the risk that the value of the collateral will fall during the course of a multi-year Chapter 11 proceeding. Other countries have gone further, imposing formal rules of partial priority in bankruptcy. ${ }^{39}$

The fact that we are already living in a world of partial priority has two very important implications. First, the adoption of a formal rule of partial priority would not necessarily be a radical change. Whether the rule would represent a radical change would depend on the degree of priority the rule accords secured claims in bankruptcy. For example, suppose that the aggregate effect of the erosion of priority currently is, on average, to reduce priority to $90 \% .{ }^{40}$ In that case, a regime which imposes a formal partial priority rule of $90 \%$ and eliminates the ad hoc erosion would not significantly differ from the current system. ${ }^{41}$ Indeed, the adoption of such a rule might represent a less radical change than moving from the current system of de facto partial priority to a system of de facto $100 \%$ priority. Thus, advocates of partial priority do not necessarily bear a greater burden of proof than those favoring full priority. ${ }^{42}$

The second important implication of the fact that we are living in a partial priority world is that those who would criticize our analysis by pointing to evidence that the existing system works perfectly well would in fact support our claim that partial priority is likely to be superior to full priority. The question, however, is whether it would work even better

37 The priority of secured claims is also eroded by state and federal law outside of bankruptcy. See Klee, supra note 32, at [110] (citing state statutes that give environmental creditors priority over mortgagees); William J. Woodward, Jr., The Carve-Out Proposal and its Critics: A Response, 30 U.C.C. L.J. 32, 34 (1997) (describing the judicial tendency to undermine priority of secured creditors); Woodward, supra note 13, at [110] (noting that state legislatures have dramatically increased the number of statutory lienholders with priority over secured creditors).

38 Bebchuk \& Fried, supra note 7, at 911-13.

39 See id. at 872 n.42; Theodore Eisenberg \& Stefan Sundgren, Is Chapter 11 Too Favorable to Debtors? Evidence from Abroad, 82 CORNELL L. REv. [101, 101] (1997) (discussing Finnish reorganizations); Klee, supra note 32, at [113] (describing partial priority rule recently adopted in Germany).

40 Of course, the actual degree of erosion might be greater or less than $10 \%$.

41 In fact, adoption of a formal partial priority rule of $90 \%$ (with no further erosion of priority) would clearly be superior to an ad hoc system of partial priority that cuts back priority by an average of $10 \%$ because there would be less uncertainty. See Bebchuk \& Fried, supra note 7, at 912 . In practice, of course, it might be difficult to eliminate all of the state and federal rules that operate to erode the priority of secured claims. However, adoption of a formal rule of partial priority might eliminate one source of this erosion by making courts that have traditionally been hostile to secured creditors on distributional grounds more inclined to respect security interests. See Woodward, supra note 13, at [107].

42 See Fried, supra note 8, at 5-7; Klee, supra note 32, at [103]. 
with a change in the degree of priority accorded to secured claims in bankruptcy (and in the way in which the priority system is implemented). That is, if currently secured creditors receive, on average, $90 \%$ of the value of their collateral, would we be better off under a regime under which that percentage is lower (e.g., 80\%) or even higher (e.g., 100\%-full priority)? And if some degree of partial priority is desirable, should we implement it in the current ad hoc manner, or should there be, as there is in a growing number of other countries, ${ }^{43}$ a formal rule of partial priority?

\section{E. Considering the Issue of Priority with an Open Mind}

In the previous sections, we have tried to show that the principle of full priority is not required by fundamental principles of contract or property law, is actually inconsistent with important principles of insolvency law, and therefore is not logically, legally, morally, or otherwise compelling. We have also explained that, as a practical matter, we are not living under a regime of full priority, but rather under one of partial priority, which means that adoption of a formal partial priority rule would not necessarily entail a radical change. In short, one should approach the question of whether we should have a rule of partial priority with an open mind.

\section{ON THE EXCESSIVE USE OF SECURITY INTERESTS UNDER FULL PRIORITY}

Those who have expressed concern about full priority in the past have generally done so on fairness and distributional grounds. ${ }^{44}$ In contrast, our analysis in The Uneasy Case has focused on the efficiency costs of according full priority to secured claims. Our view is that, even assuming that efficiency is the sole criterion for assessing the desirability of full priority, ${ }^{45}$ full priority would still be problematic. ${ }^{46}$ This Part develops and defends

43 See supra note 38 and accompanying text.

44 Commentators critical of full priority on fairness grounds have included Vern Countryman, Code Security Interests in Bankruptcy, 75 CoM. L.J. 269, 280 (1970); Grant Gilmore, The Good Faith Purchase Idea and the Uniform Commercial Code: Confessions of a Repentant Draftsman, 15 GA. L. REV. 605, 620-28 (1981); R.M. Goode, Is the Law Too Favorable to Secured Creditors?, 8 CAN. Bus. L.J. 53, 71-73 (1983-84), and more recently, Klee, supra note 32, at [103-06]; LoPucki, supra note 11, at [123]; Elizabeth Warren, Making Policy With Imperfect Information: The Article 9 Full Priority Debates, 82 CORNELl L. REv. [101, 117-22] (1997); Woodward, supra note 36, at 37-38; Woodward, supra note 13 , at [117-23].

45 We agree that a determination of the optimal priority rule will also depend on distributional considerations. See Woodward, supra note 13, at [121-22]. Unfortunately, determining the distributional effects of any given rule in bankruptcy is likely to be difficult. See Douglas G. Baird, The Importance of Priority, 82 CORNEll L. Rev. [101, 108-10] (1997). 
our claim that, under full priority, security interests will be used excessively. What we mean by excessive use of security interests is as follows: in a loan transaction that will go forward whether or not a security interest is used, full priority may cause the parties to incorporate an inefficient security interest into the arrangement, a security interest whose use in the arrangement reduces the total value available to all parties affected. ${ }^{47}$

The analysis of the problem of excessive use proceeds as follows. Under full priority, the use of a security interest can effect a transfer of bankruptcy value from nonadjusting creditors-creditors that do not adjust the terms of their loan to reflect the effect on them of the creation of security interests which, under full priority, completely subordinate the nonadjusting creditors' claims in bankruptcy. This transfer of value effectively acts as a "subsidy" for the use of a security interest, by reducing the apparent cost (or increasing the apparent benefit) to the borrower and the secured creditor of using a security interest. This "subsidy," in turn, can lead to the use of inefficient security interests.

The problem of excessive use would not arise if incorporating a security interest into a loan arrangement always added value to the transaction (which, we are assuming for now, would go forward in any event). There are, in fact, a number of ways in which the incorporation of a security interest into a loan contract can add value to such a transaction. Most of the ways in which incorporation of a security interest can add value are "priorityindependent;" they do not depend on the security interest giving the creditor full priority over unsecured claims in bankruptcy, but rather depend on the rights the security interest gives the secured creditor against the borrower and other third parties (e.g., subsequent secured creditors, transferees, and non-ordinary course purchasers). ${ }^{48}$ For example, a

46 The Uneasy Case provided what we believe is the first comprehensive analysis of how full priority can distort a debtor's arrangements with its creditors. Bebchuk \& Fried, supra note 7 . Other contributions in this area include John Hudson, The Case Against Secured Lending, 15 INT'L REV. L. \& ECON. 47 (1995); Thomas H. Jackson \& Robert E. Scott, On the Nature of Bankruptcy: An Essay on Bankruptcy Sharing and the Creditors' Bargain, 75 VA. L. REv. 155 (1989); Michelle J. White, Public Policy Toward Bankruptcy: Me-First and Other Priority Rules, 11 BeLl J. Econ. 550 (1980). For a brief discussion of this literature, see Bebchuk \& Fried, supra note 7, at 865 n.27.

47 In the subsequent Part, we will explain the efficiency costs of full priority in the context of loan transactions in which a security interest would be used whether or not secured claims are accorded full priority in bankruptcy, and in the context in which the loan transaction would not go through without the use of a security interest giving the creditor full priority in the collateral.

48 For a description of the possible "priority-independent" benefits of incorporating a security interest into a loan arrangement that will go forward in any event, see Bebchuk \& Fried, supra note 7, at 875-76. For empirical studies confirming the existence of some of these benefits, see Ronald J. Mann, Explaining the Pattern of Secured Credit, 110 HARv. L. REv. 625 (1997) [hereinafter Mann, Explaining the Pattern]; Ronald J. Mann, The Role of Secured Credit in Small-Business Lending, 86 GEO. L.J. (forthcoming 1997) [hereinafter Mann, Small-Business Lending]; Scott, supra note 5, at 933-52. There are also potential priority-dependent benefits of incorporating a security interest into a loan arrangement 
security interest may enable the lender to prevent the borrower from selling the collateral to another party and inefficiently squandering the proceeds. ${ }^{49}$

However, incorporating a security interest into a loan agreement can also give rise to various costs. Some of these costs are priority-independent, while others are prioritydependent, meaning that they arise only to the extent that secured claims are given priority over unsecured claims in bankruptcy. ${ }^{50}$ The priority-independent costs of including a security interest in a transaction that will go forward in any event include what we call "contracting costs" - the costs of creating the security interest; ${ }^{51}$ "enforcement costs"-the cost of monitoring the collateral; ${ }^{32}$ and "opportunity costs"-the potentially adverse effect of the security interest on the borrower's investment and financing flexibility in the future. ${ }^{53}$ When the costs of incorporating a security interest into a loan arrangement would exceed the benefits, the incorporation of the security interest into the loan agreement would be value-wasting. In this situation, the problem of excessive use can arise. ${ }^{54}$

that will go forward in any event (benefits which can arise only to the extent secured claims are accorded priority in bankruptcy), although we argue that they are of limited importance. Bebchuk \& Fried, supra note 7 , at $913-21$.

49 See Baird, supra note 44, at [103-04] (explaining how reducing secured creditors' priority rights over unsecured creditors still leaves secured creditors with many useful rights).

so The priority-dependent costs of security interests are discussed in Bebchuk \& Fried, supra note 7, at 897-903 and infra Parts IV.A-B.

51 Bebchuk \& Fried, supra note 7, at 877 \& nn.69-70. Contracting costs may be significant for some (but not all) secured transactions. See Mann, Explaining the Pattern, supra note 47, at 659-62; Mann, Small-Business Lending, supra note 47 , at [30-31].

52 Bebchuk \& Fried, supra note 7, at 877-78.

53 Id. \& n.72. Opportunity costs can arise whenever a firm enters into a loan agreement restricting its future course of action, but the use of the security interest in the arrangement can make these costs higher. See Mann, Explaining the Pattern, supra note 47, at 664-67.

54 Some commentators have charged that our analysis either assumes or implies that the use of secured debt is ordinarily motivated by the desire to limit the assets available to pay unsecured creditors, and not by the efficiency benefits offered by security interests. See Harris \& Mooney, supra note 11, at [106] (citing an unpublished manuscript by David Carlson arguing that we "posit[] secured credit as a zero-sum game"); Mann, Explaining the Pattern, supra note 47, at 683. But as we emphasized in The Uneasy Case (and do so again here), our analysis assumes that there are security interests whose efficiency benefits are greater than their efficiency costs. Bebchuk \& Fried, supra note 7, at 872-73, 878. Our point has been that the ability of security interests under full priority to transfer bankruptcy value from nonadjusting creditors can cause a borrower and a lender to adopt an inefficient security interest (one in which the efficiency benefits are less than the efficiency costs). See Bebchuk \& Fried, supra note 7, at 896-97. 
The rest of this Part provides a detailed analysis of the problem of excessive use. Section A reintroduces the concept of "nonadjusting" creditors-creditors that cannot or do not adjust the size of their claims against a borrower to reflect the borrower's arrangements with other creditors, including arrangements creating a security interest that subordinates the nonadjusting creditors' claims. Section B then explains why the existence of such creditors can lead to the excessive use of security interests. In Section $C$, we explain why the empirical data shows that the use of a security interest would often be value-wasting.

\section{A. The Concept of "Nonadjusting" Creditors}

In The Uneasy Case, we introduced the concept of "nonadjusting" creditors." A "nonadjusting" creditor is a creditor that, for one reason or another, cannot or does not adjust the terms of its loan to reflect the effect on its loan of all the arrangements the borrower enters into with other creditors, including the creation of security interests which, under full priority, completely subordinate the nonadjusting creditors' claim in bankruptcy. ${ }^{56}$ Because this concept is critical for understanding the problems of full priority, we want to make clear the identities of these creditors.

Before proceeding, we wish to emphasize the following. Our point is not that some nonadjusting creditors are "victimized" by priority. As we will see, some nonadjusting creditors will lose out under priority and others will not. Our point is simply this: the existence of nonadjusting creditors means that, at the moment a borrower is considering creating a security interest giving a lender priority in the underlying collateral, the borrower knows that the interest rate charged by nonadjusting creditors will be the same whether or not the borrower incorporates the security interest into the loan arrangement. This means that the borrower is able to "sell" the nonadjusting creditors' share of bankruptcy value to a secured creditor in exchange for a lower interest rate, without paying any additional interest to the nonadjusting creditors. As we explained in The Uneasy Case, the ability to sell nonadjusting creditors' share of bankruptcy value (whether those nonadjusting creditors are large banks, small trade suppliers, or tort creditors) creates a "subsidy" for the use of security interests and can cause a borrower, under full priority, to incorporate a security interest into its loan arrangements even though the security interest is value-wasting. ${ }^{57}$ Our analysis would apply even if all nonadjusting creditors received an interest rate that compensated them, on an expected value basis, for the increased risk of loss associated with the possibility of subordination. For example, our analysis would apply even in a world where the only nonadjusting creditors are sophisticated financial institutions that charge interest rates fully compensating them for the additional risk of loss associated with

ss Bebchuk \& Fried, supra note 7, at 864-65, 882-91.

${ }^{56}$ Id.

s7 Id. at $865,891-95$. 
subordination..$^{58}$ The fact that in the real world many nonadjusting creditors are not compensated for the possibility of subordination is completely irrelevant for purposes of our analysis. 59

\section{Involuntary Creditors}

The classic example of a nonadjusting creditor is a party that has been injured by the borrower and that is unable to recover fully from the borrower's insurance. ${ }^{60}$ Although uninsured tort claims do not often surface in bankruptcy, those that do turn up can be substantial. ${ }^{61}$ Because the claims are fixed by a court without regard to the borrower's financial structure, the claims of these tort creditors cannot be adjusted to reflect the existence of a security interest. The size of the tort claims will therefore neither take into account the extent to which the borrower has already encumbered its assets, nor will be subject to adjustment if the borrower subsequently subordinates the tort claims by issuing a security interest. Thus, in considering whether to create a security interest in a loan transaction, a borrower can "sell" some of what involuntary creditors would receive in bankruptcy by creating a security interest giving the secured lender priority.

Some commentators have urged that tort creditors should receive full compensation when the corporate tortfeasor goes bankrupt, either through a program of mandatory

58 For an extended example demonstrating this point, see $i d$. at 891-95.

s9 See id. at 865.

60 Although most firms purchase insurance, see David Mayers \& Clifford W. Smith, Jr., On the Corporate Demand for Insurance, 55 J. Bus. 281 (1982), the insurance they purchase may not cover all tort claims. Insurance companies typically impose limits on the scope and amount of coverage under their policies. See Henry Hansmann \& Reinier Kraakman, Toward Unlimited Shareholder Liability for Corporate Torts, 100 YALE L.J. 1879, 1889 (1991); Lynn M. LoPucki, The Unsecured Creditor's Bargain, 80 VA. L. REv. 1887, 1907 (1994). In addition, shareholders have an incentive to underinsure because they do not reap all of the benefits of the insurance they purchase. See Hansmann \& Kraakman, supra, at 1889 . Consequently, firms generally choose low insurance coverage limits and are often not insured for certain types of risks. See id. When private tort claims against the firm do arise, there is thus the possibility that they will become unsecured claims against the firm in bankruptcy.

61 In two of forty-three large reorganizations studied by Lynn LoPucki and William Whitford, tort claims-in one case for personal injury, and in the other for patent infringement-amounted to more than two-thirds of the unsecured claims against the bankrupt company. See LoPucki, supra note 58, at 1896 n.41 (citing Lynn M. LoPucki \& William C. Whitford, Corporate Governance in the Bankruptcy Reorganization of Large, Publicly Held Companies, 141 U. PA. L. REv. 669, 738 \& nn.226-27 (1993), $1906 \mathrm{n} .81$ (describing other cases in which tort liability of bankrupt firms was far in excess of the applicable insurance coverage). 
insurance or through the imposition of shareholder liability for corporate torts. ${ }^{62}$ Others have suggested that the law give tort creditors priority over secured claims ("superpriority") in bankruptcy. ${ }^{63}$ To the extent that any of these reform proposals are adopted, the parties could not use security interests to transfer bankruptcy value from tort claimants, and the problem of tort creditor nonadjustment would be eliminated. ${ }^{64}$ But as long as tort creditors are (1) not fully paid when a tortfeasor firm goes bankrupt or (2) not given superpriority over secured claims, a borrower will be able to "sell" some of the bankruptcy value that tort creditors would otherwise receive by creating a security interest that, under full priority, completely subordinates their claims.

\section{Government Tax and Regulatory Claims}

Although tort claims against a bankrupt firm may in some cases be substantial, ${ }^{65}$ in aggregate, they are not as significant as the claims of the second group of involuntary creditors-federal, state, and local government agencies.

At any given point in time, firms will typically owe payments to federal, state, and local governments for corporate income taxes, withholding taxes on employees' salaries, social security contributions, sales tax, property tax, excise tax, and customs duties. ${ }^{66}$ When the banknuptcy petition is filed, at least some of these taxing authorities will be creditors of the firm for taxes due yet not paid. In fact, tax claims against bankrupt firms are usually substantial, especially in the case of closely-held firms. ${ }^{67}$ The government may

62 See, e.g., Hansmann \& Kraakman, supra note 58, at 1887-90 (proposing unlimited shareholder liability for corporate torts); S. Shavell, The Judgment Proof Problem, 6 INT'L REv. L. \& EcoN. 45 (1986) (proposing mandatory insurance).

63 See, e.g., Kathryn R. Heidt, Cleaning Up Your Act: Efficiency Considerations in the Battle for the Debtor's Assets in Toxic Waste Bankruptcies, 40 RuTGERS L. REV. 819, 851-62 (1988); David W. Leebron, Limited Liability, Tort Victims, and Creditors, 91 CoLUM. L. REv. 1565, 1643-49 (1991); Christopher M.E. Painter, Tort Creditor Priority in the Secured Credit System: Asbestos Time, the Worst of Times, 36 STAN. L. REv. 1045, 1080-82 (1984).

64 However, as we explained in The Uneasy Case, a mandatory insurance system that permitted the insurer to reach the bankruptcy assets of the tortfeasor firm as an unsecured creditor in order to recover payments made to the firm's tort victims would not eliminate the problem of nonadjustment. In such a case, mandatory insurance would simply substitute one set of nonadjusting creditors (insurers) for another (tort creditors). See Bebchuk \& Fried, supra note 7, at 883-84 n.94. While such a substitution might be desirable for risk-spreading reasons, it would not reduce the problem of excessive use of security interests under full priority.

65 See supra note 59.

66 See 11 U.S.C. $\S 507(a)(8)(1994)$.

67 See Douglas G. Baird, The Reorganization of Closely Held Firms and the "Opt Out" Problem, 72 WASH. U. L.Q. 913, 915 (1994). 
also have environmental, pension-related, and other non-tax claims against a bankrupt firm. Although these claims will not, unlike tax claims, be present in every bankruptcy, they may be substantial when they do arise. ${ }^{68}$

The size of the government's claims against a firm is set by statute without regard to the firm's capital structure and, in particular, without regard to any security interests the firm may have created that subordinate the government's claims to those of secured creditors. Thus the government is nonadjusting with respect to the creation of security interests by the firm. That is, when a borrower and a creditor must decide whether to create a security interest, the borrower will treat its obligations to the government-like its obligations to tort creditors-as fixed, and knows that it can "sell" bankruptcy value that would otherwise go to pay government claims to the creditor in exchange for a lower interest rate.

During the Symposium, Steve Harris and Alan Schwartz argued that the government should not be considered nonadjusting because it has the power not only to change the tax laws so that its claims are "adjusted" for the creation of security interests, but also to change bankruptcy law so that its claims take priority over those of any other creditor. However, the ability (in principle) of the government to become an adjusting creditor is irrelevant. ${ }^{69}$ We are not arguing that government claims are inherently nonadjusting. Nor are we arguing that the government is victimized because it does not adjust.

Rather, we are simply pointing out that the government currently does not adjust its claims to take into account the effect on those claims of the creation of security interests which, under full priority, have the effect of subordinating those claims. Thus, when a borrower is considering the creation of a security interest giving the secured creditor priority, it knows that it can lower its overall interest burden by "selling" some of the bankruptcy value that would otherwise go to the government in exchange for lower interest payments.

\section{Voluntary Creditors with Small Claims}

Involuntary creditors-tort creditors and government agencies-are not able to adjust the size of their claims against a borrower when it creates a security interest in favor of another creditor, because their claims are fixed by law. But the fact that a creditor voluntarily contracts with a firm does not necessarily make that creditor adjusting with respect to a particular security interest which the firm has created. Many of a firm's voluntary creditors are customers, ${ }^{70}$ employees, ${ }^{71}$ and trade creditors that have relatively

68 See LoPucki, supra note 58, at 1896-97.

69 Bebchuk \& Fried, supra note 7, at 884 n.95.

o Customers may be owed money for payments made toward purchases of goods or services. For example, ticketholders had substantial unsecured claims against Braniff Airlines when it went bankrupt. 
small claims against the firm. Even though these creditors can, in principle, take the existence of a security interest into account in contracting with the firm, the small size of their claims will generally make it rational for them not to do so. ${ }^{72}$ Even trade suppliers, which are more commercially sophisticated than employees and customers, are believed to have neither the time nor the expertise to evaluate individual firm risk. ${ }^{73}$ Indeed, trade creditors generally charge uniform interest rates to all customers that are allowed to purchase on credit, ${ }^{74}$ indicating that those creditors do not set the interest rate to take into account the particular risk of loss associated with lending to that customer.

The failure of creditors with small claims to take into account a borrower's arrangements with other creditors does not imply that these creditors are systematically undercompensated for bearing the risk that other creditors of the borrower will have priority claims in bankruptcy. Experienced trade creditors probably set terms that compensate them for the average risk of loss they face in lending to all of their customers. However, whether or not these creditors are adequately compensated for their risk of loss is not relevant to our analysis. The point is simply that, when deciding whether to create a security interest giving a lender priority in the underlying collateral, the borrower knows that the decision will not affect the interest rate charged by creditors with small claims. Thus, a borrower creating such a security interest can obtain a lower interest rate by selling the bankruptcy value to

See LoPucki, supra note 58, at 1896 n.41.

71 See 11 U.S.C. $\S \S 507(a)(4)$, (b) (1994).

72 As we explained in The Uneasy Case, the cost to any creditor of adjusting its terms with a firm to reflect accurately its risk of loss in connection with lending to that particular firm is substantial, while the benefit of such an adjustment is minimal. Bebchuk \& Fried, supra note 7, at 885-86. Determining the extent of a firm's secured debt will be quite difficult. For example, although public registries identify the class of assets subject to a security interest, they do not indicate the size of the loan secured by the collateral. See Douglas G. Baird, Notice Filing and the Problem of Ostensible Ownership, 12 J. LEGAL STUD. 53, 54-55 (1983) (describing lack of information conveyed by the Article 9 notice filing system). Even if a creditor with a small claim could costlessly acquire information about the firm's secured debt, the creditor would still be required to estimate the firm's likelihood of insolvency, its insolvency value, and the extent of its unsecured debt in order to estimate its risk of loss. Finally, a creditor which had undertaken such an investigation would face the additional cost of contracting specialized terms with the firm. However, the amount owed to each of these creditors individually-and thus the expected loss faced by each creditor-is typically small. Thus the benefit to these creditors of acquiring information and negotiating special terms with the firm each time they extend credit will be minimal. See Bebchuk \& Fried, supra note 7, at 885-86.

73 See Hudson, supra note 45, at 56; Mark J. Roe, Commentary on "On the Nature of Bankruptcy": Bankruptcy, Priority, and Economics, 75 VA. L. REv. 219, 225 (1989) (commenting on Thomas H. Jackson \& Robert E. Scott, On the Nature of Bankruptcy: An Essay on Bankruptcy Sharing and the Creditors' Bargain, 75 VA. L. REV. 155 (1989)).

74 See Mitchell A. Petersen \& Raghuram G. Rajan, The Benefits of Lending Relationships: Evidence from Small Business Data, 49 J. FIN. 3, 23-25, 32 (1994). 
which these creditors would otherwise be entitled by creating a security interest under full priority. ${ }^{75}$

\section{Prior Voluntary Creditors}

We have just seen that involuntary creditors cannot adjust and that voluntary creditors with small claims generally do not adjust to the security interests created by a borrower (although some voluntary creditors with small claims may charge an interest rate that compensates them ex ante for the risk of subordination in bankruptcy). In contrast, voluntary creditors with larger claims may find it worthwhile to adjust the interest rate they charge to take into account the existence of a security interest which, in the event of bankruptcy, would give the secured creditor priority over their claims. However, a sophisticated unsecured creditor with a large claim can adjust only to security interests which the parties have already created. Thus even voluntary creditors with large claims will be nonadjusting with respect to later created security interests. Again, the point is not that the voluntary creditor is "hurt" by the subsequent creation of a security interest giving the other creditor priority; the voluntary creditor with a large claim would be expected to take into account the possibility of the subsequent creation of a security interest in setting its interest rate. The point is that, when the borrower is deciding whether or not to create a security interest in favor of a lender, it knows that the decision will not affect the interest rate charged by pre-existing unsecured creditors lending at fixed rates.

75 For an extended example, showing why it might be rational for creditors lending relatively small amounts to ignore the capital structure of the borrower in fixing their interest rates, giving some borrowers an incentive to create value-wasting security interests, see Bebchuk \& Fried, supra note 7, at 886-87. In his symposium piece, Schwartz criticizes our example. He appears to make three arguments. First, Schwartz charges that our example assumes, but does not show, that every creditor will charge the same interest rate. Alan Schwartz, Priority Contracts and Priority in Bankruptcy, 82 CoRNELl L. REV. $[101,120]$ (1997). However, there is uncontested empirical evidence that trade creditors do in fact charge every borrower to which they extend credit the same interest rate, suggesting that they are unable (or unwilling) to differentiate among these borrowers. See supra note 72 and accompanying text. Our example is designed to explain why it might be rational for creditors to behave this way, and why the observed failure of certain creditors to charge different rates of interest to different borrowers can cause some borrowers to create inefficient security interests.

Second, Schwartz argues that our example fails to explain why lenders would not eventually learn which types of borrowers issue secured debt and which ones do not, and then charge accordingly. Schwartz, supra, at [120]. The explanation is that whether or not a particular borrower creates a security interest may depend not just on the borrower's industry (e.g., retail, manufacturing) but also on the particular situation of the borrower at the time it must decide whether to borrow on a secured or unsecured basis, including, among other things, its pre-existing capital structure, the availability or lack of certain collateral. Thus at any given time, there is likely to be variation in the use of security interests within an industry, and over time there is likely to be variation in the use of security interests by a single firm. A creditor lending a small amount of money would not find it worthwhile to investigate the particular circumstances of each firm every time it extends credit.

Third, Schwartz argues that borrowers with little or no secured debt would have an incentive to signal this fact to prospective lenders. Schwartz, supra, at [121]. We respond to this argument infra Part III.B.3. 
One might ask why a voluntary creditor with a large claim would ever allow itself to become a nonadjusting creditor. That is, why would the creditor fail to simply require that the borrower covenant not to grant security interests during the term of the loan? Indeed, as discussed below, institutional creditors frequently negotiate a negative pledge covenant restricting their borrowers' ability to issue secured debt. ${ }^{76}$ The question then is why sophisticated creditors do not always use such covenants when extending a large amount of credit to a borrower. We can offer three reasons for this phenomenon. ${ }^{77}$

First, a negative pledge covenant may be inefficiently broad. Consider the case of an unsecured creditor lending to a borrower that anticipates issuing both efficient and inefficient security interests. If (a) the aggregate efficiency loss from preventing the creation of efficient security interests would be greater than the aggregate efficiency benefit from preventing the creation of inefficient security interests; and (b) the creditor and the borrower would bear all of the costs and enjoy all of the benefits of a negative pledge covenant, then the parties will not find it worthwhile to negotiate a negative pledge clause, even though the borrower may later create an inefficient security interest subordinating the unsecured lender's claim.

Second, even when a negative pledge covenant would not be too broad, the unsecured lender and the borrower may not use it if they cannot capture enough of the benefits that would be generated by the covenant. In particular, to the extent that the borrower has other (nonadjusting) unsecured creditors, some of the benefits of the arrangement will be captured by these other creditors. ${ }^{78}$ In that case, the borrower and the unsecured creditor contemplating the use of a negative pledge covenant may not adopt it even if it would create value. ${ }^{79}$

Third, even if a negative pledge covenant (a) would create value and (b) would (if enforceable) privately benefit the borrower and the unsecured lender, the parties may not use it if-as is often the case-the lender believes that such a provision would be difficult to

${ }^{76}$ See infra Part III.C.2.

$n \quad$ For a more detailed discussion, see Bebchuk \& Fried, supra note 7, at 888-91.

78 Because these other creditors are nonadjusting, the adoption of a negative pledge covenant in the loan arrangement will not cause them to lower the interest rates they charge the borrower. As a result, the borrower does not capture any of the benefit that would accrue to these creditors.

79 Thus, the failure of a borrower and an unsecured creditor to negotiate a negative pledge covenant, the failure of a negative pledge covenant to ban all types of secured debt, or the willingness of an unsecured creditor to waive a negative pledge covenant does not, unlike some commentators have argued, prove that the parties expect that it will be efficient for the borrower to create the security interests that the unsecured creditor does not prohibit. Schwartz, supra note 73, at [118]. For further discussion of the inferences that one can draw from negative pledge covenants, see Bebchuk \& Fried, supra note 7, at 922-23; infra Part III.C.2. 
enforce. ${ }^{80}$ Under current law, the claim of an unsecured creditor that has bargained for a negative pledge covenant is subordinated by a security interest created in violation of a negative pledge covenant. ${ }^{81}$ In many cases, the lender would have difficulty both preventing the borrower from creating such a security interest and then determining that such a security interest had been created. ${ }^{82}$

A negative pledge covenant is not the only method that an unsecured creditor could use to ensure that it does not become nonadjusting with respect to a subsequently created security interest. For example, sophisticated unsecured creditors could build an adjustment mechanism into their contracts with borrowers which allows them to reset the interest rate if the borrower subsequently creates a security interest. Unlike a negative pledge covenant, an adjustment mechanism negotiated between an unsecured lender and a borrower does not prevent the borrower from creating a value-creating security interest: it merely increases the cost of doing so. As long as the cost is not so high that it precludes the creation of the security interest, the adjustment mechanism, unlike a negative pledge covenant, would not be overbroad. Nor would such a mechanism confer a benefit on any other creditors. Thus, the parties are more likely to adopt an efficient adjustment mechanism than a negative pledge covenant.

Although sophisticated creditors with large claims might find such mechanisms

80 See Bebchuk \& Fried, supra note 7, at 888.

81 See id. at 889 n.116 (citing Equitable Trust Co. v. Imbresi, 412 A.2d 96 (Md. 1980) (holding that mortgagee had priority in property encumbered by borrower in violation of covenant); Mann, Explaining the Pattern, supra note 47, at 643). One commentator has proposed making recorded negative pledge covenants enforceable against third parties. See Carl S. Bjerre, . We think that his proposal deserves serious consideration. \{CORNELL L. REV. EDITORS-I AM IN THE PROCESS OF OBTAINING BJERRE'S MANUSCRIPT AND WILL ASK HIM TO SEND YOU ONE DIRECTLY, BY FEDEX OR EMAIL\}

82 See Bebchuk \& Fried, supra note 7, at 888-90. The creation of a security interest will be undetectable for as long as the security interest is not perfected (recorded). In many cases, it is also difficult to detect a recorded security interest. See Mann, Explaining the Pattern, supra note 47, at 643.

Because an unperfected security interest would not give the secured lender priority over the negative pledge lender (once the lender obtains a judgment lien), some readers questioned our claim that an "informal creditor' [e.g., a friend or family member of the business owner] need not perfect its security interest for its claim to have priority over that of the [negative pledge] unsecured lender." Bebchuk \& Fried, supra note 7, at 888. We made this claim because between the time that (1) the negative pledge lender discovers the security interest and (2) the negative pledge lender obtains a court judgment against the borrower (which might be months, or longer), the secured creditor would have time to perfect the security interest (giving it priority over the negative pledge lender) or simply to seize the collateral (making it unavailable to the negative pledge lender). Thus, our claim is that the "informal" creditor need not perfect its security interest for its claim to have effective priority over that of the unsecured lender. 
worthwhile in principle, adjustment mechanisms are generally considered to be impractical. ${ }^{83}$ Given that the appropriate adjustment factor for each security interest would depend on numerous parameters-such as the likelihood of the borrower's insolvency-that would be realized only at the time the security interest is created, it would be extremely difficult to specify the appropriate schedule of interest rate adjustments in advance. ${ }^{84}$ Moreover, such a contractual provision-like a negative pledge covenant-might be difficult to enforce against smaller companies that can easily conceal a financing transaction and that may lack the funds to pay the adjustment once the transaction is discovered. Thus, even if an appropriate adjustment schedule could be specified in advance at no cost, there might be situations in which a sophisticated creditor would not reduce the interest rate it charged a borrower in exchange for an adjustment mechanism.

In any event, even if some prior sophisticated creditors with sufficiently large claims did adopt such an interest rate adjustment mechanism, other prior creditors would be nonadjusting with respect to the creation of subsequent security interests by the borrower. Thus the borrower would still have an incentive-albeit a reduced one-to create security interests in order to transfer value from nonadjusting creditors.

We again want to emphasize that, while prior voluntary creditors might not be able to adjust to the creation of a security interest by the borrower, we are not assuming that they are exploited by the borrower. In fact, we are willing to assume that prior creditors anticipate the risk that subsequent security interests will subordinate their claims in bankruptcy and charge accordingly. The only assumption on which our analysis depends is that the terms negotiated by almost all prior creditors, however set, are fixed by the time the borrower and a potentially secured creditor negotiate their loan transaction. Thus when the borrower and the potentially secured creditor shape their arrangement, the use of a security interest giving the creditor a secured claim with full priority-compared to an arrangement without such a security interest-can make the borrower better off by allowing it to "sell" to the creditor bankruptcy value that would otherwise be enjoyed by these prior nonadjusting creditors.

B. Nonadjusting Creditors and the Use of Inefficient Security Interests

\section{The Problem}

We are now ready to consider how full priority and the presence of nonadjusting creditors affects the incentives of borrowers and creditors contemplating the use of a security

83 See, e.g., Kanda \& Levmore, supra note 5, at 2112 (observing that variable interest rate arrangements have high transaction costs).

84 Although the parties could instead renegotiate the terms of the loan contract following the creation of each security interest, it would be costly for the parties to verify the appropriate parameters and bargain over the adjustment every time after the creation of a security interest. Such a scheme would therefore also not be practical. 
interest in connection with a loan transaction that will proceed whether or not a security interest is used. Recall that the steps in the analysis are as follows: (1) under full priority, the use of a security interest can effect a transfer of bankruptcy value from nonadjusting creditors; (2) this transfer of value acts as a subsidy for the use of a security interest, by reducing the apparent cost (or increasing the apparent benefit) to the borrower and the secured creditor of using a security interest; and (3) this "subsidy" can lead to the use of inefficient security interests. Below, we provide a simple example to illustrate these points. ${ }^{85}$

To begin, suppose that a borrower and creditor $C 1$ are contemplating incorporating a security interest into their loan arrangement. Under full priority, one effect of incorporating a security interest is that, everything else equal, in the event of bankruptcy, creditor $C l$ will receive more than it would without the security interest, and other creditors will receive less. Everything else equal, creditor $C 1$ should therefore be willing to charge the borrower a lower interest rate. To the extent these other creditors are adjusting, the borrower will be required to "pay" for transferring the bankruptcy value from these creditors to creditor $C 1$ through a higher interest rate charged by these other creditors. But at least some of the borrower's creditors will be nonadjusting. Suppose that the effect of incorporating the security interest under a rule of full priority is to transfer an expected value of $\$ 10$ from these nonadjusting creditors.

The presence of nonadjusting creditors means that, by creating a security interest in favor of creditor $C 1$, the borrower can "sell" $\$ 10$ of expected bankruptcy value to creditor $C 1$ in exchange for a lower interest rate without "paying" for the transfer through higher interest rates to nonadjusting creditors. The transfer of $\$ 10$ in expected bankruptcy value to creditor $C 1$ should, everything else equal, cause creditor $C 1$ to reduce the interest it charges the borrower by the same amount- $\$ 10$. From the borrower's point of view, this transfer reduces the apparent cost of creating the security interest by $\$ 10$ (or, equivalently, increases the apparent benefit of creating the security interest by $\$ 10$ ).

The fact that the security interest would transfer $\$ 10$ from nonadjusting creditors to the borrower may, in turn, affect the borrower's decision whether to grant creditor C1 a security interest. Suppose, for example, that the creation of the security interest would give rise to an efficiency cost of $\$ 15$ and provide an efficiency benefit of $\$ 10$ (excluding the transfer of $\$ 10$ from nonadjusting creditors) and that the borrower and creditor $C 1$ would bear all of the efficiency costs and capture all of the efficiency benefits. Such a security interest would be value-wasting. If all of the creditors were adjusting, the borrower and creditor $C 1$ would not have an incentive to adopt the security interest because, without the transfer, the security interest would impose a net cost of $\$ 5$. However, if the effect is to transfer $\$ 10$ from nonadjusting creditors, the borrower and creditor $C 1$ will have an incentive to adopt the security interest. The reason is that the apparent benefit to the borrower and creditor $C 1$ of adopting it appears to be $\$ 20$ (rather than $\$ 10$ ), an amount greater than the

85 For a more extended treatment, see Bebchuk \& Fried, supra note 7, at 891-95. 
cost of $\$ 15$ (or, equivalently, the apparent cost is now only $\$ 5$, less than the benefit of $\$ 15$ ).

Before proceeding, we would like to emphasize two important points. First, we are not arguing that incorporation of a security interest into a loan transaction (that will go forward in any event) will always have the effect of transferring value from nonadjusting creditors. The creation of a security interest giving the secured creditor bankruptcy priority will, everything else equal, transfer value from nonadjusting creditors by reducing their fractional share of the bankruptcy pie. But, as we have emphasized, the incorporation of such a security interest into a loan agreement will also affect unsecured creditors in two other ways: (1) by affecting the probability that the borrower will fail and (2) by affecting the amount of assets that will be available in the event of bankruptcy. Depending on the circumstances, the use of a particular security could either increase or decrease the probability of failure, and either increase or decrease the amount of assets that will be available to creditors as a group. ${ }^{86}$ Thus the use of a security interest under full priority in connection with a loan transaction that will go forward in any event will make unsecured creditors better off overall, if the subordination effect is outweighed by the other two effects. $^{87}$

But by the same reasoning, unsecured creditors may be in an even worse position after the creation of a security interest than if the only effect of the security interest is to reduce their fractional share of the borrower's bankruptcy assets. In particular, and as we explain in the next Part, under full priority the incorporation of a security interest not only subordinates the claims of unsecured creditors, but also, by reducing the incentive of the secured creditor to monitor the borrower, it may increase the probability of failure and reduce the amount of assets that are available to pay all claims in the event of default. That

86 The use of a security interest will tend to increase the probability of failure and/or reduce the amount of assets that are available to creditors as a group, to the extent that the security interest imposes priority-independent costs on the borrower (including "opportunity costs"), see Bebchuk \& Fried, supra note 7, at 872-73; supra notes [49-53] and accompanying text, and to the extent that the protection provided by the security interest reduces the lender's incentive to monitor the borrower. See Bebchuk \& Fried, supra note 7, at 897-903; infra Part IV.A-B. The use of a security interest will tend to decrease the probability of failure and/or increase the amount of assets that are available to creditors as a group, to the extent that it permits the lender to better control the actions of the borrower (e.g, prevent the borrower from selling the collateral and transferring the proceeds to its shareholders). See Bebchuk \& Fried, supra note 7, at 876 (discussing priority-independent efficiency benefits that arise from special rights accorded to secured creditors outside of bankruptcy).

87 A related, but distinct point is that the use of a security interest under full priority, in connection with a transaction that would not go forward under less than full priority can also make unsecured creditors better off. See Bebchuk \& Fried, supra note 7, at 919-20. Not surprisingly, those favoring full priority emphasize this point. See Harris \& Mooney, supra note 11 , at $[102,106]$. We will address the efficiency effects of priority on transactions that will not go forward unless there is full priority in Part V (where we will point out that full priority can also make unsecured creditors worse off by enabling inefficient transactions to go forward). For now, however, we continue to focus only on transactions that would go forward whether or not a security interest is used. 
is, the incorporation of a security interest into a loan agreement may make unsecured creditors worse off in not one, but three ways: (1) by increasing the probability of the borrower's failure; (2) by reducing the amount of assets that will be available to all creditors in the event the borrower fails; and (3) by reducing unsecured creditors' fractional share of these assets.

The second point to be emphasized is that a particular security interest's potential, under full priority, to transfer value from nonadjusting creditors does not mean that the borrower and a potentially secured creditor would always have an incentive to use the security interest. The borrower and the potentially secured creditors would have an incentive to use a security interest if the efficiency benefits they capture from the security interest, plus the (expected) transfer of value from nonadjusting creditors, is greater than the efficiency costs they will bear from the use of the security interest. Thus the fact that a security interest under full priority can transfer value from nonadjusting creditors does not imply that lenders and borrowers would always use security interests in their loan arrangements. ${ }^{88}$

\section{Excessive Use Can Occur Without Involuntary Creditors}

The presence of nonadjusting creditors can lead to the use of value-wasting security interests, whether or not nonadjusting creditors are hurt. ${ }^{89}$ To show that value-wasting security interests might be used under full priority, even though no involuntary nonadjusting creditors are hurt, suppose that, in the example above, all of the nonadjusting creditors are voluntary.

Suppose, for example, that all of the nonadjusting creditors are large unsecured lenders that have lent at fixed interest rates before the borrower faces the decision of whether to create a security interest as part of its loan arrangement with creditor $\mathrm{Cl}$ that will have the effect of, among other things, increasing the expected value of creditor $\mathrm{Cl}^{\prime}$ 's bankruptcy claim by $\$ 10$, and reducing that of the nonadjusting creditors' bankruptcy claims by the same amount.

In principle, the creditors extending large loans to the borrower before the borrower enters into a transaction with creditor $C l$ can compensate themselves ex ante, via a higher interest rate, for the possibility that, when the borrower and creditor $C I$ negotiate their loan arrangement, the borrower will create a security interest that, everything else equal, reduces the expected value of their bankruptcy claims by $\$ 10$. So while the incorporation of a security interest into the loan arrangement with creditor $C l$ will, at that time, make these nonadjusting creditors worse off than if a security interest is not

${ }^{88}$ Consequently, the failure of borrowers to secure all of their assets does not, as Schwartz has argued, see Schwartz, supra note 73, at [115-17], prove that borrowers cannot use security interests to transfer value from unsecured creditors. For further discussion on the inferences that can be drawn from the use of unsecured debt, see infra Part III.C.1.

89 See Bebchuk \& Fried, supra note 7, at 891-95. 
incorporated into the loan arrangement, they will not be worse off than they would have been in a world where there is no priority because they will have been compensated for the risk of subordination by a higher interest rate. At the same time, because the terms will be set at a fixed amount that will not be adjusted whether or not creditor $C 1$ gets a security interest, there will still be a subsidy in favor of using a security interest, and this subsidy could lead to the use of a security interest even if it reduces the total value of the transaction.

\section{Can Disclosure by Borrowers Eliminate the Problem of Excessive Use?}

In his symposium paper, Alan Schwartz makes the point that although it may not be worthwhile for creditors with small claims to determine whether a borrower has created security interests that would subordinate their claims in the event of bankruptcy, the borrower could provide such information at low cost. ${ }^{90}$ Firms that have not created security interests would, Schwartz argues, have an incentive to bring this to the attention of lenders of small amounts in order to induce the lenders to lower their interest rates. ${ }^{91}$ This information would permit lenders with small claims to adjust their interest rates to reflect the existence (or non-existence) of particular security interests. ${ }^{92}$ The implication of Schwartz's analysis appears to be twofold. First, with respect to borrowers that already provide this information to creditors with small claims, the amount of nonadjustment may not be as large as we suggest, at least with respect to creditors with small claims. Second, with respect to borrowers that do not find it worthwhile to provide this information, we can infer that the amount of nonadjustment by creditors with small claims is fairly small because; otherwise, borrowers with little secured debt in their financial structure would have an incentive to notify creditors of that fact.

Of course, Schwartz's point is applicable with respect to only one of the four groups of nonadjusting creditors-creditors with small claims. Clearly, notification would not cause involuntary, government, or prior creditors to become adjusting. The absence of borrower-notification would also not indicate that the amount of nonadjustment by these three other classes of nonadjusting creditors is insignificant.

Moreover, notification is unlikely to be able to cost-effectively reduce nonadjustment (and, therefore, the absence of notification is not likely to indicate that the magnitude of nonadjustment is small) for creditors with small claims that could in principle adjust the size of their claims to take into account the existence of previously-issued secured debt in the borrower's financial structure. The cost of effectively communicating one's financial structure to these creditors may not be insignificant. First, the debtor will have an incentive to mislead because the debtor would face liability only in the event it cannot pay its creditors, at which point the debtor has already failed, and the additional liability is of no

\footnotetext{
90 Schwartz, supra note 73, at [121-23].

91 Id. at [121].

92 See id.
} 
consequence. Thus there must be a third party involved to provide verification. ${ }^{93}$ Second, accuracy would require that disclosure be continuous; otherwise, lenders would suspect that, since the previous disclosure, the borrower had significantly changed its financial structure to their detriment. Third, and most importantly, even if the borrower could cheaply provide up-to-date accurate information about its financial structure, creditors with small claims would still bear the cost of assessing the information provided by the borrower and the cost of negotiating special rates. When the amount of the loan, and therefore the expected risk of loss, is relatively small, it will simply not be worthwhile for the creditor to incur these processing and negotiation costs. Moreover, even in the absence of those costs, many creditors with small claims-including the borrower's employees and customers-are not sophisticated enough to adjust the (implicit) rate they charge a borrower to take into account the existence or non-existence of secured debt in the borrower's financial structure.

In short, borrower disclosure is unlikely to convert creditors with small claims into adjusting creditors, and in any event could not cause the other three classes of nonadjusting creditors (tort creditors, the government, and creditors with prior claims) to become adjusting.

\section{Empirical Evidence That Security Interests Are Often Inefficient}

We have shown that parties might create security interests even if they are inefficient. The pending question is whether there are many cases in which security interests actually are inefficient. In this Section, we present empirical evidence that indicates that this is the case.

\section{The Persistence of Unsecured Debt}

Although there is very little data on the extent of secured lending in the U.S. economy, there is no question that it is an important form of financing for many companies. Almost $30 \%$ of the dollar volume of commercial bank loans is secured. ${ }^{94}$ Of course, the same data also show that a substantial amount of debt (including $70 \%$ of the dollar volume of commercial bank loans) is not secured. Indeed, not only are many loans unsecured, but many companies borrow on an exclusively unsecured basis. It is well known, for example,

93 Much of this information is available through Dun and Bradstreet, UCC filings, and other sources. But often these sources are not accurate. See Bebchuk \& Fried, supra note 7, at 885 n.103; Mann, Explaining the Pattern, supra note 47, at 643-44.

94 See Allen N. Berger \& Gregory F. Udell, Collateral, Loan Quality, and Bank Risk, 25 J. MONETARY ECON. 21, 31 (1990). Because non-bank loans are more frequently secured than bank loans, the percentage of the total dollar volume of business lending that is secured is even higher. See John D. Leeth \& Jonathan A. Scott, The Incidence of Secured Debt: Evidence from the Small Business Community, 24 J. Fin. \& Quantitative ANALysis 379, 379 (1989) (citing studies from the early 1980s suggesting that nearly $80 \%$ of dollar volume of business loans was secured). 
that large companies rarely issue secured debt. ${ }^{95}$ And, even among small businesses-the type of firms most likely to rely on secured financing-a substantial percentage borrow exclusively on an unsecured basis: almost $50 \%$ of small businesses that borrow from banks do not provide collateral for their loans. ${ }^{96}$ Almost $40 \%$ of small companies do not rely on any secured credit financing whatsoever. ${ }^{97}$

The failure of many loan transactions to incorporate security interests provides evidence that the use of security interests can entail significant costs. As we saw in Section $B$ above, the use of a security interest allows a borrower to transfer bankruptcy value from nonadjusting creditors. Thus the failure to use a security interest implies that the efficiency costs of the security interest that would be borne by the borrower and the sophisticated creditor are greater than the efficiency benefits they would enjoy from the security interest plus the expected transfer of bankruptcy value made possible by the current priority regime. ${ }^{98}$ This, in turn, suggests that the use of a security interest in these cases would be inefficient.

However, the failure of a lender to incorporate a security interest into its loan arrangement with a borrower does not prove that a security interest would have been valuewasting because the creation of a security interest, even under a rule of priority, can, in principle, make nonadjusting creditors better off. ${ }^{99}$ Thus even under full priority a borrower and lender contemplating the use of a value-increasing security interest in their loan arrangement might choose not to incorporate the security interest into the loan arrangement

${ }_{95}$ See James R. Booth, Contract Costs, Bank Loans, and the Cross-Monitoring Hypothesis, $31 \mathrm{~J}$. FIN. ECON. 25, 40 n.10 (1992) (reporting that firms with public debt rarely borrow on a secured basis).

Soe Leeth \& Scott, supra note 96, at 387.

97 See Trends Tracked in Banking Practices of Small Businesses, J. Acct., Oct. 1987, at 36, 39.

98 Although the current system is one of de facto partial priority, see supra Part I.D, it still permits a borrower to transfer value from nonadjusting creditors by issuing a security interest. Of course, the expected value of this transfer will be low if there is little likelihood that the borrower will default. Thus one might suggest that the borrowers from which sophisticated lenders do not take security interests are those that are unlikely to fail. However, the widespread use of negative pledge covenants, see infra Section III.C.2, indicates that sophisticated creditors believe that, even with respect to firms that borrow mostly on an unsecured basis, the risk of failure is sufficiently high to make it worth negotiating for a provision that ensures that their claims will not be subordinated in bankruptcy. Because the use of these provisions indicates creditors' concerns with their standing in bankruptcy, it stands to reason that these creditors would place at least some value on the bankruptcy priority accorded by a security interest. Thus the failure of a sophisticated creditor to use a security interest in any given case suggests that the efficiency cost of using a security interest might have been substantial. It is also worth noting that small firms, which have a much higher failure rate than larger firms, frequently borrow exclusively on an unsecured basis. See supra note 91 and accompanying text.

99 See Bebchuk \& Fried, supra note 7, at 919-20; supra note 84 and accompanying text. 
because they do not capture enough of the benefits to make it worthwhile. ${ }^{100}$

\section{Negative Pledge Clauses}

The widespread use of negative pledge covenants-provisions in loan agreements that severely restrict the borrower's ability to incur secured debt-provides evidence that the creation of a security interest can often make unsecured creditors worse off. Unsecured creditors would not seek these provisions if these provisions did not make them better off. These provisions would not make unsecured lenders better off unless the creation of the security interests prohibited by the provisions would make them worse off. Thus the existence of these provisions indicates that the creation of security interests can make unsecured creditors worse off.

The fact that borrowers agree to these provisions provides additional information. Negative pledge covenants impose a substantial cost on borrowers by preventing borrowers from collateralizing loans in the future (in order to get cheaper financing, or perhaps in order to get any financing). The fact that a borrower agrees to such a covenant thus indicates not only that the creation of a security interest prohibited by the covenant would make the lender worse off, but also that the creation of the security interests would hurt the lender more than it would help the borrower. In other words, the provision increases the size of the pie that the two parties can share.

If the lender and the borrower were the only parties affected by the arrangement, the existence of a negative pledge covenant would suggest that the covenant is efficient, and, therefore that the creation of the security interests prohibited by it would be inefficient. ${ }^{101}$

100 The fact that a borrower and a creditor contemplating taking a security interest in the borrower's property may choose to forego using a value-creating security interest because they do not capture a sufficient portion of the efficiency benefits raises an interesting point: full priority may reduce the insufficient use of value-creating security interests. Suppose that under partial priority, a borrower and a creditor do not find it worthwhile to use a value-creating security interest because the portion of the efficiency benefits they capture, plus the expected transfer of bankruptcy value under partial priority, is less than the portion of the efficiency costs that they bear. And suppose that under full priority, the borrower and the creditor would find it worthwhile to use that security interest because the portion of the efficiency benefit they capture, plus the expected transfer of bankruptcy value under full priority is greater than the portion of the efficiency costs, that they bear. In that case, full priority would confer an efficiency benefit by encouraging the use of a value-creating security interest that a borrower and a creditor would not otherwise use. However, the fact that the advocates of full priority have not made this argument may indicate that this benefit is likely to be insignificant.

101 Alan Schwartz is correct to point out that the existence of a negative pledge covenant does not prove that "'it would be inefficient to create ... security interests [that would be] prohibited by its terms." Schwartz, supra note 73, at [122-23 n.57] (quoting Bebchuk \& Fried, supra note 7, at 923). Like any covenant, the negative pledge covenant can be overbroad. Our claim is therefore that, at the time the covenant is written, the parties believe that there is a net efficiency gain to prohibiting a broad range of security interests (even though some of those security interests might add value to a future 
However, the two parties do not capture all of the net benefit created by the provision, as some of the benefit flows to nonadjusting unsecured creditors. For example, the provision ensures that unsecured creditors' loans are not subordinated during the term of the negative pledge lender's loan. Therefore, such restrictions mean that the negative pledge lender's share of the net benefits derived from not creating the security interest is greater than the entire cost borne by the borrower's owners. In other words, the provision is so efficient (or, equivalently, the creation of the security interests would be so inefficient) that even though the negotiating creditor cannot capture all of the benefits from the provision, the two parties still find it worthwhile to include the provision in the loan agreement.

Of course, the fact that negative pledge clauses, when value-creating, confer a benefit on other creditors means that there are many times when they are not used by unsecured lenders even though they would be efficient. ${ }^{102}$ There are also many times that negative pledge clauses are not used because the lender takes a security interest that is less efficient, but more privately beneficial because of the resulting transfer of value. ${ }^{103}$ Thus the widespread use of negative pledge clauses understates the extent to which the creation of security interests would be inefficient. ${ }^{104}$

transaction, or permit an efficient transaction to go forward). However, Schwartz is incorrect to argue that the willingness of a negative pledge creditor to waive the restriction (in exchange for a higher interest rate, a security interest, or some other compensation) proves that the secured transaction thereby agreed to is efficient. One cannot draw the inference that a security interest created as the result of a waiver is efficient because the other parties affected do not receive the same compensation as the negative pledge creditor, and thus may be made worse off by the secured transaction. If the waiver and resulting secured transaction make the lender and the borrower better off, but make other (uncompensated) creditors worse off by a greater amount, then the secured transaction would be inefficient.

102 See Bebchuk \& Fried, supra note 7, at 889; supra notes 76-79 and accompanying text.

103 For another reason why lenders would not use negative pledge clauses even when such a clause is efficient, see Bebchuk \& Fried, supra note 7, at 888-89 (explaining that lenders may not use negative pledge covenants where the debtor's future borrowing is difficult to monitor, where the benefits may not flow to the creditor, and where a negative pledge covenant would be overbroad).

104 To be sure, the widespread use of negative pledge covenants in the U.S. takes place under the current system of de facto partial priority. As we explained in The Uneasy Case, certain efficiency benefits of security interests are "priority-dependent." Bebchuk \& Fried, supra note 7, at 914-21. That is, these benefits arise only to the extent secured claims are accorded priority in bankruptcy. See id. Because these efficiency benefits would be greater under a true full priority regime, one might argue that the existing behavior of sophisticated creditors and their borrowers fails to demonstrate that the use of security interests would often be inefficient under a true full priority regime. However, we also explained in The Uneasy Case and in this article as well that there are significant inefficiencies that arise when secured claims are accorded full priority in bankruptcy. Bebchuk \& Fried, supra note 7, at 918-21; infra Part IV. Under a true full priority regime, these inefficiencies would be greater than they currently are. Thus the inference that some scholars draw from the existing use of negative pledge covenants may actually understate the extent to which the use of security interests would be inefficient under a full priority regime. 


\section{Who is Hurt by the Use of Security Interests Under Full Priority?}

In Section A, we explained that there are four classes of nonadjusting creditors that cannot or do not adjust the size of their claims against the borrower to take into account the borrower's arrangements with other creditors, including the use of security interests that, under full priority, would have the effect of reducing the expected value of the nonadjusting creditors' bankruptcy claims. In Section B, we explained why the existence of these creditors could cause a borrower to incorporate a security interest into a loan arrangement even though the security interest would not add value to the arrangement. In Section C, we presented evidence that the use of security interests would, in fact, often be value-wasting. In this Section, we identify the parties that ultimately bear the efficiency costs associated with the creation of value-wasting security interests. As explained below, the cost is spread among many different parties, including borrowers.

Perhaps the easiest way to identify the parties hurt by the creation of value-wasting security interests is first to identify the two types of parties that, in aggregate, are not hurt. The two groups that do not bear the efficiency cost associated with the use of value-wasting security interests are (1) adjusting creditors and (2) nonadjusting creditors that set an interest rate that, on average, compensates them for the risk of loss they face in extending credit including trade suppliers, commercial lenders, and others. Every other party affected is hurt, in one way or another, by the creation of value-wasting security interests.

Consider first involuntary nonadjusting creditors such as tort creditors and the government. Unlike other groups that might, in theory, be able to charge a price that compensates them for the increased risk of loss due to the use of a value-wasting security interest, involuntary creditors cannot. These nonadjusting creditors thus bear part of the costs arising from the use of value-wasting security interests. ${ }^{105}$ Certain voluntary nonadjusting creditors that do not always deal with the borrower on terms that reflect their expected risk of loss due to the borrower's use of a value-wasting security interest and that cannot diversify the risk, for example, the borrower's employees and customers, might also bear part of the cost.

Next consider borrowers as a class. To the extent that adjusting and sophisticated nonadjusting creditors charge higher interest rates to reflect the risk of loss due to the creation of value-wasting security interests, borrowers' profits are reduced. Note that sophisticated nonadjusting creditors will charge a higher interest rate to any borrower that could potentially create value-wasting security interests subordinating their claims. If in the end, all borrowers do create value-wasting security interests, then each borrower will ultimately bear the cost through higher interest rates that would otherwise be imposed on adjusting and sophisticated nonadjusting creditors. However, if some borrowers create security interests and others do not, and nonadjusting creditors are unable to distinguish between these two types of borrowers, then both types of borrowers will pay higher interest

105 Of course, these creditors will also bear some of the costs associated with the other inefficiencies arising out of full priority. See infra Part IV. 
rates for unsecured credit even though one type will create value-wasting security interests and the other will not. In essence, the higher interest rates paid by borrowers that do not create value-wasting security interests will subsidize the use of value-wasting security interests by other borrowers. ${ }^{106}$ This cross-subsidization effect means that borrowers creating security interests do not necessarily internalize the full cost of the security interests they create.

\section{ON THE OTHER EFFICIENCY COSTS OF FULL PRIORITY}

In Part III, we examined one efficiency cost of full priority: in loan transactions that would go through whether or not the parties use a security interest, full priority may cause the borrower to create a security interest even though it does not add value to the transaction. This Part further develops and defends our claim that full priority produces at least three other efficiency costs: (1) in a loan transaction in which the parties will use a security interest whether or not secured claims receive full priority in bankruptcy, according full priority to secured claims may undesirably reduce the secured creditor's monitoring of the borrower; (2) the possibility of borrowing later on a secured basis under full priority may cause a borrower to make inefficient decisions with respect to potential tort liability; and (3) when a loan transaction will not go through unless the lender is given a security interest providing it with full priority in the underlying collateral, full priority may permit the financing of undesirable activities. ${ }^{107}$

\section{A. Reduced Monitoring by Secured Lenders Under Full Priority}

A potentially large efficiency cost of according full priority to secured claims is that full priority reduces the incentive of the secured creditor to "monitor" the debtor, that is, attempt to prevent the debtor from engaging in value-wasting activities, known as "misbehavior." 108 The intuition here is simple: to the extent the secured creditor is insulated from

106 For a simple example of this cross-subsidization effect, see Bebchuk \& Fried, supra note 7, at 887.

107 Our analysis below of these three costs draws on, and further develops, material in Bebchuk \& Fried, supra. There are other possible costs of full priority which we did not examine in The Uneasy Case and which we will not examine here, including the possible detrimental effect of full priority on the ability of firms to reorganize themselves in Chapter 11. See infra Part VI.C.

108 Bebchuk \& Fried, supra note 7, at 897-903. One commentator, asserting that in The Uneasy Case, we use the term "misbehavior" to describe conduct by a borrower that does not further the interests of the lender, argues that such a characterization is "erroneous because it ignores the fact that the borrower is just as independent an economic actor, and therefore just as entitled to pursue its own interests, as the lender." Mann, Explaining the Pattern, supra note 47 at 649 n.89. In The Uneasy Case, we indicated that we use the term "misbehavior" to mean "inefficient behavior." Bebchuk \& Fried, supra note 7, at 872. The use of the term misbehavior is not meant to imply that inefficient behavior by the borrower is necessarily illegal, immoral, or otherwise blameworthy. And we would not consider an efficient 
risk of loss because it has full priority in the collateral subject to the security interest, it has less incentive to monitor the borrower for misbehavior. Full priority is likely to have two distinct effects on a secured creditor's incentive to monitor the borrower: (1) full priority will reduce the secured creditor's incentive to incorporate additional covenants into the loan agreement, for example, provisions aimed at preventing the borrower from engaging in certain types of undesirable behavior and (2) even if full priority does not reduce the secured creditor's incentive to incorporate additional covenants into the loan agreement, it will reduce the secured creditor's incentive to attempt to enforce the covenants it has incorporated into the loan agreement, as well as whatever creditor rights state debtor-creditor law provides. $^{109}$

\section{Reduced Use of Covenants}

When a borrower and a creditor have adopted a security interest, full priority makes it less likely that the two will include in their arrangement a set of covenants that would be efficient for them to adopt. This problem may arise even if the security interest giving the creditor full priority adds value to the arrangement. The point is that the arrangement would be even more value-adding if it also included the covenants that, as a result of full priority, the arrangement does not incorporate.

In a perfect world in which the terms of other creditors' arrangements fully reflect the consequences to them of all of the elements of the arrangements into which the borrower enters, the two parties would have an incentive to adopt any covenant that is efficient because they would capture all of the resulting benefits. In our world, however, nonadjusting creditors would capture part of the benefits and bear none of the costs of any covenants which the creditor and the borrower negotiate. Consequently, even if the set of covenants were efficient when considering its total benefits, it would not be privately beneficial for the borrower and creditor to adopt if the cost to the borrower outweighed the benefits accruing to the creditor (and any other adjusting creditors).

Although this problem-that a borrower and creditor will have an insufficient incentive to adopt efficient covenants-is generally true whenever there are creditors whose claims do not fully reflect the agreement between the borrower and creditor, the problem

activity that runs counter to the interest of the lender as misbehavior, even if the activity would violate the loan agreement. (To the extent the borrower is unable to engage in an efficient activity because of the loan agreement, we would consider that result an "opportunity cost" of the loan arrangement. See supra note 52 and accompanying text.)

109 For a discussion of how lenders monitor borrowers' behavior through various features of their loan agreements, see Raghuram Rajan \& Andrew Winton, Covenants and Collateral As Incentives to Monitor, 50 J. FIN. 1113 (1995). There are a number of theories addressing how full priority could assist the monitoring of a borrower. We reviewed these theories in The Uneasy Case, and explained why we believe that full priority is unlikely to offer significant monitoring benefits. Bebchuk \& Fried, supra note 7, at 913-17. During the Symposium, no one expressed support for full priority on these grounds, so we will not restate these theories and our analysis of them here. 
becomes even more severe if the two parties adopt a security interest under the rule of full priority. In such a case, the creditor's risk of loss will be reduced and, therefore, the benefit to the creditor of an additional set of covenants will be even smaller. ${ }^{110}$ The creditor is thus even less likely under a rule of full priority to adopt a covenant that is highly efficient. ${ }^{111}$

\section{Reduction in Monitoring}

We have just seen that, in the presence of nonadjusting creditors, full priority may cause a borrower and a creditor to forego the use of desirable covenants even if they use an otherwise value-creating security interest in the arrangement. However, even if full priority has no effect on the use of covenants in the arrangement, ${ }^{112}$ full priority will inefficiently reduce the creditor's enforcement of its loan contract with the borrower. In particular, full priority will give the creditor less incentive to enforce any loan contract covenants with the borrower or to force the borrower into bankruptcy when it would be socially desirable for the borrower to liquidate or reorganize. ${ }^{113}$

In discussing full priority's effect on the use of covenants in loan arrangements, we abstracted from the level of the creditor's enforcement efforts-the activities the creditor undertakes to ascertain that the borrower is complying with its contractual commitments. However, a borrower's incentive to comply with the covenants it has issued may depend on the extent of the creditor's enforcement efforts. That is, the less the creditor monitors the borrower's compliance with these commitments, the less likely it is to detect a breach. Hence, it will be more likely that the borrower will find the expected cost of breach to be less than the expected benefit of breach, and therefore will violate the covenants. To the extent the covenants bar the borrower from engaging in inefficient activities, the level of the

110 If the credtor's loan is fully secured, and there is sufficient excess collateral to fully cover the creditor's collection costs and any unpaid interest, then its risk of loss will approach zero. Cf. Hudson, supra note 45 , at 52 (observing that a bank with a secured loan will have no incentive to use its knowledge of the debtor optimally because it is fully protected from risk of loss).

111 For an extended example, see Bebchuk \& Fried, supra note 7, at 900-01. The point that a creditor taking security is less likely to "monitor" the debtor through other contractual restrictions is well understood in the literature. See Buckley, supra note 5, at 1440; Jackson \& Kronman, supra note 5, at 1153; Triantis, supra note 5, at 244. For empirical evidence that secured lenders adopt fewer covenants, see Kenneth Lehn \& Annette Poulsen, Contractual Resolution of Bondholder-Stockholder Conflicts in Leveraged Buyouts, 34 J.L. \& EcoN. 645, 660-68 (1991).

112 One can imagine a number of cases in which the priority rule does not affect a creditor's use of covenants. For example, a bank may use the same standardized loan contract whenever it extends credit to a particular class of borrowers irrespective of whether it also takes a security interest. See Bebchuk \& Fried, supra note 7, at 902 n.150. Another example might be financing sellers, which may or may not take a security interest when they extend credit, but rarely employ covenants in either case.

113 See Bebchuk \& Fried, supra note 7, at 902-03; Woodward, supra note 36, at 35-37. 
creditor's enforcement efforts will therefore have efficiency implications.

Even in the absence of priority, the creditor will engage in less than the optimal amount of enforcement activity because some of the benefit of this activity will flow to other creditors, yet it (and the borrower) will bear all of the costs. However, the creditor will have even less of an incentive to engage in enforcement activities to the extent that a security interest giving the creditor's claim full priority in bankruptcy protects the creditor from risk of loss, just as it will have less incentive to adopt even highly efficient covenants. As a result, the borrower may be more likely to violate a covenant and act inefficiently under a rule of full priority if the creditor has a security interest. Thus, even if full priority does not lead to the creditor's and borrower's adoption of fewer covenants, it may well degrade the effectiveness of the covenants they do adopt and lead to efficiency problems by reducing the creditor's incentive to monitor the borrower's compliance with those covenants. ${ }^{114}$

Under the rule of full priority, a secured creditor that is well protected by collateral does not have sufficient incentive to call a default (or cut off funding) when the borrower's owners attempt to continue operating inefficiently to avoid losing the business. ${ }^{115}$ Because in many cases a borrower's unsecured creditors will neither have the information nor the sophistication to force the borrower into bankruptcy, ${ }^{116}$ there will be an efficiency loss until the secured creditor forces the borrower to cease operating. ${ }^{117}$ Thus, even if the creditor and borrower did not include any covenants in the loan agreement other than a default clause, the rule of full priority, by tending to insulate the creditor from the effects of the borrower's collapse, does not provide the creditor with the proper incentive to terminate its

114 Even those who support the rule of full priority recognize the problem that a fully secured creditor will suboptimally monitor the borrower. See, e.g., Buckley, supra note 5, at 1440-41. Because all contracts between commercial borrowers and creditors implicitly incorporate the mandatory rules that govern the debtor and creditor relationship, such as fraudulent conveyance law and corporate law limitations on payments to shareholders, this problem will arise even if the two parties do not choose to adopt other covenants. See Bebchuk \& Fried, supra note 7, at 903 n.151.

115 It is widely understood that under full priority a secured creditor with influence over a borrower may not act optimally on the eve of bankruptcy. See Hudson, supra note 45, at 49; Jackson \& Scott, supra note 45, at 170-71; White, supra note 45, at 554-55.

116 See Elizabeth Warren, Bankruptcy Policy, 54 U. CHI. L. REv. 775, 794 (1987).

117 Some commentators have argued that monitoring is ineffective because the secured creditor will react to borrower misbehavior by seizing the collateral, leaving the unsecured creditors with nothing. See Lisa M. Bossetti \& Mette H. Kurth, Professor Elizabeth Warren's Article 9 Carve-Out Proposal: A Strategic Analysis, 30 U.C.C. L.J. 3, 20-21 (1997). However, these commentators miss two important points. First, the threat of foreclosure deters borrowers from engaging in activities that adversely affect unsecured creditors. Second, by shutting down a company that is operating inefficiently, a secured creditor prevents a borrower from incurring more debts to current and future unsecured creditors (including the government, employees, customers, and trade creditors) which it is unlikely to be able to repay. 
relationship with the borrower. ${ }^{118}$

\section{B. Inefficient Decisions with Respect to Potential Tort Liability}

As we saw, full priority may affect a borrower's behavior following a loan transaction, if the effect of full priority is to cause the creditor to fail to incorporate various covenants into the arrangement or enforce those that are incorporated. However, the borrower's ability to give the creditor a security interest that subordinates the claims of nonadjusting creditors may affect the borrower's behavior even before the creditor and the borrower negotiate their loan contract.

Consider the case where the borrower must decide, prior to contracting with the creditor, whether to take certain precautions that will make its products safer and reduce the number of future tort claims against the borrower. The borrower knows that when the creditor and the borrower later negotiate their loan contract, the creditor will take expected tort claims into account in setting its interest rate. If the creditor is unsecured, the creditor will charge the borrower a higher interest rate, to the extent it anticipates that future tort claims will reduce the value of its loan by diluting the creditor's share of the borrower's bankruptcy assets. By adjusting its interest rate to take into account the expected number of tort claims, the creditor will force the borrower to internalize more of the costs of the tort claims that are likely to arise if it fails to take these precautions. If the creditor is expected to be unsecured, the prospect of paying a higher interest rate to the creditor will increase the incentive for the borrower to take the precautions in the first place.

Under the rule of full priority, however, the borrower may give the creditor a security interest that protects the value of the creditor's loan from the dilutory effect of tort claims. Consequently, if the creditor is given a security interest, it may not charge a higher interest rate even if the borrower fails to take precautions, and there are more tort claims against the borrower. Because the borrower will not face the prospect of paying the creditor a higher interest rate if more tort claims against it are likely, the borrower will have less incentive to invest in precautions if it knows that it can grant the creditor a security interest

118 Full priority can also give a secured creditor insufficient incentive to provide additional credit to a borrower when avoiding bankruptcy would be efficient. See Klee, supra note 32, at [108]. In The Uneasy Case, we cited Dean Scott's empirical study of borrower-lender relationships and an article by a senior bankruptcy judge to support our claim that a "bank will be able to exert a significant amount of influence over the borrower. Indeed, a bank will frequently determine whether or not a borrower files for bankruptcy and the timing of any filing. Thus, the bank is in a unique position to control a borrower's behavior." Bebchuk \& Fried, supra note 7, at 903 (citations omitted). Some readers have interpreted this to mean that we believe the bank "controls" the business of the borrower. We are not claiming that the secured lender runs the borrower's business, which might expose it to lender liability. We are simply making the familiar point that by threatening to call a default (or by calling a default), a bank has a tremendous amount of leverage over a financially-distressed borrower. See LoPucki, supra note 11, at [111-12]; Mann, Explaining the Pattern, supra note 47, at 646-48. 
giving the creditor's secured claim full priority. ${ }^{119}$

With respect to this particular efficiency cost of full priority, Harris and Mooney argue that tort liability generally has little to no effect on the borrower's behavior. ${ }^{120}$ Therefore, the borrower's ability to reduce the effect of tort liability by issuing security interests under the rule of full priority should not, they argue, have much effect on the borrower's decisions whether to take precautions or to refrain from activities likely to generate tort claims.

We do not share the view that tort liability has little effect on firm behavior, for there is substantial evidence that tort liability does affect firm behavior. For example, firms invest in precautions that have the effect of reducing their expected tort liability. Firms would not incur such expenses if they were indifferent to their expected tort liability.

Harris and Mooney argue in the alternative that even if tort liability does affect firm behavior, firms' ability to reduce the cost of tort liability by issuing secured debt under a rule of full priority is likely to have only a minimal effect on tort liability and therefore on firm behavior. Whether full priority has a small or large effect on tort liability is, of course, an empirical question to which we currently do not have an answer. ${ }^{121}$ Nevertheless, it is worth emphasizing that even if full priority has only a limited effect on expected tort liability, and therefore on firm behavior, partial priority may still yield substantial benefits in terms of reducing expected tort liability. For example, a slight increase in expected tort liability might cause firms to adopt, at little expense, additional precautions that have a substantial effect on the amount of expected harm.

\section{Funding of Marginal Activities}

So far we have discussed three efficiency costs of full priority: (1) in loan transactions that will go through in any event, full priority may cause a borrower to incorporate a security interest into the arrangement even though it is value-wasting; (2) in loan transactions that will use a security interest regardless of the priority rule in bankruptcy, full priority may undesirably reduce the secured creditor's incentive to monitor the borrower; and (3) the prospect of borrowing on a secured basis under full priority may cause a firm to undesirably reduce its investment in precautions or to undesirably engage in more activity likely to give rise to tort liability.

The fourth efficiency cost of full priority is that it may facilitate loan transactions

119 Both those favoring and those critical of the rule of full priority recognize the use of security interests to permit the borrower to bear less of the claims. See Buckley, supra note 5, at 1417; LoPucki, supra note 58, at 1898.

120 Harris \& Mooney, supra note 11, at [115-24]

121 It is easy, of course, to construct a numerical example showing that a particular rule has no effect on a firm's behavior. See Bossetti \& Kurth, supra note 114, at 18-19. 
that enable the borrower to fund inefficient investments. The intuition here is simple: when there are nonadjusting creditors, the creation of a security interest giving a lender full priority creates a subsidy not only for the use of the security interest in the arrangement, but also for the transaction itself. Thus, a transaction that would not go forward without such a subsidy might go forward with such a subsidy. We will defer further discussion of this efficiency cost of full priority until Part VI, where we discuss the effect of partial priority on the financing of good and bad projects.

\section{ON THE DESIGN OF PARTIAL-PRIORITY RULES}

We have seen that full priority can produce significant efficiency costs. However, it would not be desirable to adopt a rule of partial priority if either (a) the efficiency costs of such a rule would be even larger; or (b) such a rule could not be effectively implemented. Before considering these issues (as we do in Parts VI and VII), it is necessary to explain how partial priority might be implemented. Therefore, this Part presents and discusses three possible partial priority rules. We first restate the two partial-priority rules we put forward and analyzed in The Uneasy Case (the "fixed-fraction priority rule" and the "adjustablepriority rule"). ${ }^{122}$ We then introduce a third possible rule (the "consensual priority rule").

The three partial priority rules can be summarized as follows: Under the "fixedfraction priority rule," a fixed fraction of the collateral backing secured claims would be made available to pay the claims of unsecured creditors. ${ }^{123}$ The "adjustable-priority rule" accords secured claims priority only over the claims of nonadjusting creditors. ${ }^{124}$ Finally, under the "consensual priority rule," secured claims would have priority only over the claims of creditors that had explicitly consented to subordination.

We wish to emphasize that none of these partial-priority nules would be superior in every respect to the rule of full priority. There will be efficiency costs associated with these rules or any rule of partial priority. Thus, although some commentators have read The Uneasy Case as advocating adoption of a partial priority rule, ${ }^{125}$ we tried to make clear in our earlier paper and will restate here that, at this point, we merely think that these rules should be considered with an open mind as alternatives to full priority. ${ }^{126}$

\footnotetext{
122 Bebchuk \& Fried, supra note 7, at 904-11.

123 Id. at $909-11$.

124 Id. at 905-09.

125 See, e.g., LoPucki, supra note 11, at [101-02]; Mann, Explaining the Pattern, supra note 47, at 683 n.228; Mann, supra note 11 , at 45-46 \& n.134.
}

126 Bebchuk \& Fried, supra note 7, at 904, 934. 
Before proceeding with descriptions of these rules, we also must re-emphasize three points. First, the purpose of these rules is not to protect unsecured creditors, although all of these rules might have the effect of making certain groups of unsecured creditors, such as involuntary creditors and unsophisticated creditors that do not set their interest rate to reflect the risk of loss from the borrower's failure and the subordination of their claims (e.g., customers and employees), better off. The purpose of these rules is to reduce the efficiency costs associated with full priority. ${ }^{127}$

Second, although some commentators have characterized the two rules we put forward in The Uneasy Case as "a subordination scheme," nates the claims of secured creditors to those of unsecured creditors: under all three of the rules secured claims would receive at least as much as unsecured claims. Indeed, neither of the two rules we considered in The Uneasy Case would completely eliminate the priority accorded to secured claims in bankruptcy. Rather, these partial priority rules would affect only the degree to which the secured creditor enjoys priority in its collateral over unsecured creditors when the debtor enters bankruptcy. ${ }^{129}$ Furthermore, under all three of the partial priority rules we consider, a secured creditor would continue to enjoy full priority in its collateral over the claims of subsequent secured creditors, transferees, nonordinary course purchasers, and unsecured creditors that had consented to subordination. ${ }^{130}$ Finally, none of these priority rules would have any effect on the secured creditor's rights outside of bankruptcy. That is, none of the rules would require modifying Article 9 of the UCC or the state laws governing transactions in real property. ${ }^{131}$

Third, there is no need to apply the same partial priority rule in every context. Some symposium participants expressed concern that imposing a partial priority rule in certain contexts (e.g., securities loans among financial institutions) would achieve little benefit and give rise to potentially large costs. To the extent that there are particular transactions that should not be subject to partial priority, they could be exempted. ${ }^{132}$ In general, secured creditors could be given different degrees of priority in their collateral depending on the type of collateral, the size of the loan, and the type of the lender and/or

127 In a world without priority but with nonadjusting creditors, the problems that we identify would continue to arise, albeit to a lesser degree. See Baird, supra note 44, at [109-10].

128 Harris \& Mooney, supra note 11, at [118].

129 Under the third rule, a secured creditor would not enjoy any priority over the claim of an unsecured creditor that had not explicitly consented to subordination. Instead, the secured creditor and the unsecured creditor would both share pro rata in the collateral. See infra Part V.C.

130 Thus, any of the rules would be compatible with any system of priority among secured claims.

131 Therefore, the adoption of any of the rules would not affect the priority-independent efficiency benefits connected with security interests. See Bebchuk \& Fried, supra note 7, at 875-76.

132 See Klee, supra note 32, at [113-14]; Mann, supra note 11, at 14. 
borrower. $^{133}$

\section{A. The Fixed-Fraction Priority Rule}

Under the fixed-fraction priority rule, a secured creditor would receive full priority with respect to a certain percentage of its secured claim. The collateral backing the rest of the claim would be made available to pay unsecured claims (including that portion of the secured creditor's secured claim that was made unsecured by operation of the rule). Thus, under a rule giving secured creditors $75 \%$ of their secured claim, the other $25 \%$ of the collateral would be distributed to pay unsecured claims-including the unsecured claims of all secured creditors. ${ }^{134}$ The fixed-fraction priority rule would always leave secured claims partially unsecured, even if the value of the collateral exceeds the amount owed to them. ${ }^{135}$

To illustrate the operation of the fixed-fraction partial priority rule, we will consider the version in which the secured creditor receives priority with respect to $75 \%$ of its secured claim. Assume that when the borrower goes bankrupt, it has $\$ 1.2$ million in assets and owes $\$ 1$ million to each of three creditors: the secured creditor, an adjusting creditor, and a nonadjusting creditor. Assume that the creditor has a security interest with respect to all $\$ 1.2$ million of the borrower's assets. Its secured claim-which is the lesser of the amount owed and the value of the collateral-would thus be $\$ 1$ million. Under a $75 \%$ fixed-fraction priority rule, the creditor will receive $\$ 750,000$ of the encumbered assets. The remainder of its claim, $\$ 250,000$, would be made unsecured and pooled with those of the other two creditors. The $\$ 450,000$ in assets available to pay unsecured claims would then be distributed to the three creditors in proportion to their unsecured claims so that the $\$ 2.25$ million in unsecured claims $\$ 2$ million in claims by the adjusting and nonadjusting creditors

133 We agree with those who argue that in designing a bankruptcy system attention must be paid to underlying commercial practices. Mann, supra note 11, at 48. However, commercial practices evolve rapidly and are in part shaped by the rules used to govern them. Thus it would be fruitless and perhaps counterproductive to try to fashion a different priority rule for each commercial context.

134 In 1985, the German Commission on Bankruptcy Law proposed a variant of the fixed-fraction priority rule as a replacement for the rule of full priority in German bankruptcy law. See Drukarczyk, supra note 5, at $205 \& \mathrm{n} .8$. The proposal recommended that secured creditors receive only $75 \%$ of the amount of their secured claims collateralized by personal property on the grounds that personal property liens in Germany are difficult to discover, and that, as we have argued, exposing secured creditors to increased risk of loss is likely to encourage more desirable monitoring of their borrowers. See id. at 205. Although this proposal was never adopted, the new German Insolvency Law, adopted in 1994, incorporates several new administrative fees that have the effect of reducing the priority of secured claims in bankruptcy by $9 \%$ of the value of personal property collateral. See Bebchuk \& Fried, supra note 7, at 909-10; Klee, supra note 32, at [113].

135 Contrary to the claims of some commentators, the fixed-fraction rule would not "limit] security interests to a percentage of a borrower's collateral." Bossetti \& Kurth, supra note 114, at 4. Under the $75 \%$ fixed-fraction rule, a borrower could encumber all of its collateral. However, in bankruptcy, at least $25 \%$ of the encumbered collateral would be made available to pay the claims of unsecured creditors. 
and $\$ .25$ million of the secured creditor's secured claim which is rendered unsecured by operation of the rule) would be paid 20 cents on the dollar. Thus, the secured creditor would receive $\$ 50,000$ for its unsecured claim and the other creditors would receive $\$ 200,000$ each. ${ }^{136}$

As we explain in The Uneasy Case, the fixed-fraction priority rule would reduce the ability of creditors and their commercial borrowers to use security interests to transfer value from nonadjusting creditors by not allowing secured claims to fully subordinate nonadjusting claims in bankruptcy. ${ }^{137}$ The fixed-fraction priority rule would thus also decrease the excessive use of security interests, the distortion in monitoring arrangements that commercial borrowers and their creditors adopt, and (as we will explore in more detail below), the funding of undesirable business activities. The reduction of these distortions would depend on the percentage of the secured claim that is treated as unsecured: the larger the percentage, the greater the reduction in the identified efficiency costs. In the extreme case where the entire secured claim is treated as unsecured, the parties could not use a security interest to transfer value in bankruptcy, and the inefficiencies that full priority causes would be completely eliminated. ${ }^{138}$

136 One person has suggested to us that the rule would "double-compensate" adjusting creditors by giving them some of the secured creditors' collateral even though they had adjusted to the security interest by charging a higher interest rate. If a creditor is adjusting, however, it will charge a lower interest rate than it would under full priority to reflect the fact that it will receive a larger fraction of the borrower's bankruptcy estate. As a result, the fixed-fraction rule will not double-compensate the creditor.

137 Bebchuk \& Fried, supra note 7, at 910.

138 See id. at 910 . Ronald Mann has argued that in the context of construction finance, his proposal to give the claims of contractors priority over the claims of (secured) construction lenders would be superior to a fixed-fraction rule which, in this context, would give secured construction lenders partial priority over contractors. Mann, supra note 11, at 46-48. Although his carefully-researched proposal may well be worth adopting, his claim that a contractor-first rule gives construction lenders more incentive to control risk than a fixed-fraction rule is not necessarily correct. Relative to a fixed-fraction rule, a contractor-first rule would force construction lenders to internalize more of the costs that would otherwise fall on contractors, giving construction lenders more of an incentive to reduce the risk of loss faced by this class of creditors. However, unlike a fixed-fraction rule, a contractor-first rule would not force construction lenders to internalize any of the costs imposed on other creditors, including tort creditors, the government, and other nonadjusting creditors of the property owner, thereby giving them less incentive to reduce the risk of loss faced by these classes of creditors. Depending on the fraction of secured claims that the fixed-fraction rule would treat as unsecured, and the size of these creditors' claims relative to the claims of contractors, a fixed-fraction rule might provide construction lenders with more of an incentive to reduce the risk of loss faced by other creditors.

However, we must emphasize that the purpose of our rules is to reduce the efficiency costs that arise from priority, not to solve all of the possible problems that can arise in contracting between borrowers and creditors. See Bebchuk \& Fried, supra note 7, at $904 \mathrm{n} .158$. On that score, a rule such as Mann's that gives superpriority to a limited class of nonadjusting creditors (while reducing the inefficiencies that result from the presence of those nonadjusting creditors) will not reduce the efficiency problems arising from priority to the extent that they are caused by the presence of involuntary creditors 


\section{B. The Adjustable-Priority Rule}

The other partial priority rule we put forward in The Uneasy Case is the adjustablepriority rule. ${ }^{139}$ Under the adjustable-priority rule, claims of nonadjusting creditors would not be subordinated to secured claims with respect to which they were nonadjusting. In other words, a nonadjusting creditor's share of bankruptcy value would be calculated by (1) assuming that the secured claims with respect to which the creditor was nonadjusting were actually unsecured claims, and (2) applying the rule of full priority. The difference between what the nonadjusting creditor would receive under the rule of full priority and what it receives under the adjustable priority rule would come at the expense of the secured claims with respect to which it was nonadjusting. Adjusting creditors would receive what they would have received under the rule of full priority.

One might question whether a bankruptcy court could in fact identify those creditors that were nonadjusting with respect to a particular security interest in order to enforce such a rule. In The Uneasy Case, we address the feasibility of implementing the adjustable-priority rule, and will not do so again here. ${ }^{140}$ Below, we will simply assume that the court is able to identify a debtor's nonadjusting creditors to show how the rule would work under ideal conditions.

Suppose again that a borrower goes into bankruptcy with $\$ 1.2$ million in assets and outstanding liabilities of $\$ 3$ million, of which $\$ 1$ million is owed to the secured creditor, $\$ 1$ million is owed to an adjusting unsecured creditor, and $\$ 1$ million is owed to a nonadjusting creditor. Again, assume that $\$ 1.2$ million of the assets are subject to a security interest which the creditor holds.

In the absence of any priority, the $\$ 1.2$ million in assets would be divided on a pro rata basis with each creditor receiving $\$ 400,000$. Under the rule of full priority, assuming that all unsecured creditors share pro rata in the remaining assets, the creditor will receive $\$ 1$ million and the remaining $\$ 200,000$ in assets will be divided equally between the other two creditors. The result under full priority is that $\$ 300,000$ of bankruptcy value is transferred from each unsecured creditor to the secured creditor. The secured creditor thus benefits under the full priority rule at the equal expense of both the adjusting and the nonadjusting creditor.

Under the adjustable-priority rule, the creditor's claim would be treated as unsecured for the purpose of determining the nonadjusting creditor's share before application of the rule of full priority. As a result, the nonadjusting creditor in this example would be entitled to receive $\$ 400,000$. The difference between what the nonadjusting creditor would

and other voluntary nonadjusting creditors. See id. at 907-08.

139 Id. at 905.

140 Id. at $908-09$. 
have received under the rule of full priority- $\$ 100,000$-and what it received under the adjustable-priority rule- $\$ 400,000$, or $\$ 300,000$ - would come at the expense of the creditor's secured claim. The adjusting creditor would receive what it would have obtained under full priority, $\$ 100,000$, and the secured creditor would thus receive $\$ 700,000$.

Because the use of the security interest would not affect the nonadjusting creditor's share of bankruptcy value, the adjustable-priority rule would ensure that the security interest could not be used to transfer bankruptcy value from nonadjusting creditors. Thus, if such a rule could be fully implemented, it would eliminate the inefficiencies we identified-the use of inefficient security interests, the monitoring distortions, and the funding of undesirable projects-to the extent they arise out of full priority.

It is worth emphasizing that an adjustable-priority rule is not the same as a rule that would give certain creditors superpriority over secured creditors' claims. For example, a growing number of commentators have proposed that tort or other claims receive superpriority over secured claims (or certain secured claims) in bankruptcy. ${ }^{141}$ The goal of these proposals has been to increase firms' incentives to reduce harmful externalities on third parties. As we explained in Part IV, the borrower's ability to subordinate unsecured creditors' claims by issuing security interests, giving the secured lender priority, enables the borrower to internalize less of the costs it imposes on these parties than it would under a rule of pro rata sharing in bankruptcy (as under the adjustable-priority rule). Superpriority would thus force borrowers to internalize even more of these costs than pro rata sharing, and presumably would lead borrowers to take even better precautions and choose even better projects than under a pro rata rule. However, superpriority for tort claimants would, at best, somewhat reduce, and certainly not eliminate, the efficiency problems that full priority causes. As explained, the efficiency costs of according full priority to secured claims arise because of the existence of nonadjusting creditors, most of which are voluntary creditors or government agencies. Thus, giving superpriority to tort claims would immunize tort creditors from the effect of priority, thereby reducing the efficiency costs to the extent that they are due to the presence of tort creditors. However, such a scheme would not, unlike the adjustable-priority rule, reduce the distortions and efficiency costs that the presence of contractual nonadjusting creditors and government claims causes.

\section{A Consensual Priority Rule}

In The Uneasy Case and this paper, we have argued that full priority is inconsistent with the general commercial law principle against nonconsensual subordination. ${ }^{142}$ The fixed-fraction priority rule would also allow nonconsensual subordination, although to a

141 For recommendations that tort creditors receive priority over the claims of other creditors, see Barry E. Adler, Financial and Political Theories of American Corporate Bankruptcy, 45 STAN. L. REV. 311, 340 (1993); Leebron, supra note 61, at 1650; LoPucki, supra note 58, at 1907-08; Painter, supra note 61, at 1088-81; Roe, supra note 71, at 227.

142 Bebchuk \& Fried, supra note 7, at 868-70. 
lesser degree than full priority. Similarly, the adjustable-priority rule-even if it could be implemented so that secured creditors received priority only over the claims of adjusting creditors-would not require adjusting creditors' explicit consent for subordination. Thus, both rules would be at least somewhat inconsistent with the general principle that a borrower cannot subordinate the claims of particular creditors without their explicit consent.

The third rule we put forward-the consensual priority rule-would harmonize the priority system with the general principle against nonconsensual subordination by giving a secured creditor priority in its collateral only over the claims of creditors that had explicitly consented to subordination. The explicit consent might be with respect to a particular security interest or all security interests which the borrower creates. In any event, the consent must be explicit.

To the extent that a borrower's creditors are contractual, the borrower would be able to obtain these contractual creditors' consent to subordination. Thus, such a rule would not prevent the borrower and its creditors from contracting for full priority. ${ }^{143}$ However, a creditor that had not explicitly consented to subordination would receive a bankruptcy share equal to that which it would have received if all of the creditors were unsecured and shared pro rata in the bankruptcy assets.

\section{Why Not Partial Priority Outside of Bankruptcy?}

The rules we describe would apply in bankruptcy. However, it is important to emphasize that we are not advocating, as others have suggested, ${ }^{144}$ that partial priority apply only in bankruptcy. If partial priority is superior to full priority, we think that this distributional principle should apply to any liquidation or reorganization of an insolvent firm, either inside or outside of bankruptcy.

As a practical matter, however, it makes sense to consider first rules that would apply only in bankruptcy. ${ }^{145}$ First, it would be simpler to make changes to bankruptcy laws than it would be to make uniform changes to the various state laws that govern priority in personal property and real property. ${ }^{146}$ Second, there is no need to apply partial priority to solvent firms (and there may well be costs). A bankruptcy-only rule ensures that the rule will apply only to firms in financial distress.

143 Under the other two partial priority rules, a borrower and its contractual creditors could also, by contract, subordinate the claims of certain creditors to the claims of others.

144 See, e.g., LoPucki, supra note 11, at [106-07].

145 Many others apparently share the view that if partial priority is to be adopted, it should be adopted only in bankruptcy. See Klee, supra note 32, at [103 n.11]; LoPucki, supra note 11, at [102 nn.3, 5] (citing those advocating a bankruptcy-only approach).

146 See Klee, supra note 32, at [114]; LoPucki, supra note 11, at [103 n.8]. 
Of course, a bankruptcy-only rule will not be as effective as a more widely implemented rule. ${ }^{147}$ However, as we will explain below, we think that a bankruptcy-only partial priority rule could still be quite effective. ${ }^{148}$

\section{ON THE COST AND AVAILABILITY OF FINANCING UNDER PARTIAL PRIORITY}

Various symposium participants and others have expressed concern that a partial priority rule would have an adverse effect on the financing of business activity. ${ }^{149}$ That is, partial priority might make it more difficult for businesses to finance desirable (valueincreasing) projects.

Before we analyze this claim in more detail, three points are worth noting upfront. First, in a world where not all business projects are value-increasing, the desirability of a partial priority rule's effect on firms' ability to finance their projects will depend not only on whether partial priority prevents some desirable projects from going forward, but also on whether it prevents some undesirable projects from going forward. To be specific, a partial priority rule's effect on firms' ability to finance their projects would actually be desirable (relative to an alternative rule) if the economic cost avoided when bad projects do not go forward is greater than the economic benefit lost when desirable projects do not go forward.

Second, the magnitude of the effect of a partial priority rule on the financing of projects will depend on the degree to which the rule continues to respect priority. Suppose that under our current ad hoc system of partial priority, secured claims are paid, on average, 90 cents on the dollar. If that is the case, replacing the current system with a $90 \%$ fixedfraction priority rule is likely to have little effect on the financing of business activity, for better or for worse. A partial priority rule of $50 \%$ would, of course, have a larger effect, and so on.

Third, even if a partial priority rule's net effect on the financing of projects is undesirable (e.g., the economic cost arising from the failure of good projects to be financed is greater than the economic benefit arising from the failure of bad projects to be financed), the overall economic effect of partial priority may still be desirable because partial priority will provide other benefits that could offset the negative net effect on project financing. In particular, a partial priority rule might reduce the excessive use of security interests, lead to better monitoring of firms that do receive financing, and give firms more incentive to avoid externalizing harms on third parties. Thus, even if one believes that a particular partial

\footnotetext{
${ }^{147}$ See LoPucki, supra note 11 , at [123-24, 129-30].

148 See infra Part VII.B.

149 See, e.g., Harris \& Mooney, supra note 11, at Part II.A; Klee, supra note 32, at [107-09]; Turner, supra note 6 , at 328-29.
} 
priority rule's net effect on financing projects is negative, one should still be open-minded as to whether the rule is worth adopting.

\section{A. Some Preliminary Points}

To begin, we want to make some general points on the cost and availability of credit under partial priority. Our claim is that, on an aggregate basis, the availability and cost of credit need not change substantially under a rule of partial priority.

\section{The Availability of Secured Credit Under Partial Priority}

One argument against partial priority is that certain lenders will not lend at any interest rate unless they have full priority in the collateral that is subject to the security interest. $^{150}$ The evidence adduced in support of this claim is that currently there are lenders that will not lend unless they receive a security interest. Supporters of full priority argue that under partial priority these lenders simply will not lend money to borrowers at any interest rate and, therefore, that partial priority will reduce the amount of credit these lenders extend. (Presumably, those who make this argument would also claim that under partial priority, unsecured creditors would not be more willing to supply credit, so that the total supply of credit would be reduced.) ${ }^{151}$

Let us assume, arguendo, that currently, certain lenders will not lend without getting a security interest. Even if this assertion were true, it certainly does not prove that these lenders will not lend under a rule of partial priority. After all, these lenders are currently operating under a system of de facto partial priority. ${ }^{152}$ The assertion proves only that under the current rule of partial priority, certain lenders require a security interest.

The question, then, is whether reducing the degree of priority in bankruptcy will cause these lenders not to lend. This, in turn, will depend on why these lenders will not lend without a security interest (again, assuming, arguendo, that these lenders would in fact not lend without a security interest). For our purposes, there are two possible reasons why certain lenders currently will not lend without a security interest: (1) because the security interest gives the lender priority over the claims of unsecured creditors in bankruptcy or (2) because the security interest gives the lender priority-independent rights (for example, priority over the claims of transferees or subsequent secured creditors) that are unrelated to the lender's priority in bankruptcy over the claims of unsecured creditors.

Suppose that the reason that certain lenders will not lend without a security interest is that security interests afford the lender priority in bankruptcy over the claims of unsecured

\footnotetext{
150 See Harris \& Mooney, supra note 5, at 2030-35; Kripke, supra note 5, at 954-55 \& n.95.

151 There is, however, evidence to the contrary. See Mann, Small-Business Lending, supra note 47, at [12-15] (reporting that small commercial borrowers have alternatives to secured credit).
}

152 See supra Part II.D. 
creditors. Currently, secured claims do not get full priority in bankruptcy. ${ }^{153}$ Thus, these lenders clearly do not require full priority, and are satisfied with partial priority. The question, then, is how much priority is necessary to induce these lenders to lend? $90 \%$ ? $80 \%$ ? And how much priority would a secured lender require if it also obtained a guarantee from the borrower's owners? ${ }^{154}$

Now suppose that the reason why certain lenders will not lend without a security interest is that the security interest gives lenders many other rights which are connected not to the priority accorded to secured claims in bankruptcy, but rather to something else. For example, it is possible that many lenders will not lend without a security interest because they have no other means of preventing the borrower, should it be on the verge of failing, from liquidating its assets and distributing the proceeds to related parties. To the extent certain lenders insist on a security interest for this reason, a partial priority rule in bankruptcy will not cause these lenders to lend any less. In short, we are skeptical of the claim that if priority is further reduced, the supply of secured credit will materially decrease (while, according to the same claim, the supply of unsecured credit would remain the same). ${ }^{155}$

133 See supra Part II.D.

154 A guarantee can add value to the transaction by aligning a firm's owners' interests with those of its creditors. See LoPucki, supra note 58, at 1915-16; Mann, Small-Business Lending, supra note 47, at [24-27]. For a general economic analysis of guarantees, see Avery Wiener Katz, An Economic Analysis of the Guaranty Contract (Jan. 21, 1997) (unpublished manuscript). A separate question-which we address infra at Parts VI.B-C-is if lenders do not lend with say, $80 \%$ priority, are the projects that would go unfunded generally value-increasing projects or value-reducing projects?

155 To support the claim that it is necessary to give secured creditors full priority over the claims of unsecured creditors in bankruptcy, some commentators point to evidence that there is inadequate lending in third-world countries without functional security systems. See Harris \& Mooney, supra note 11, at [110 n.35]; Turner, supra note 6, at 329. For two reasons this evidence fails to support their claim. First, creditors in these countries might restrict their lending not because they lack priority in their collateral over the claims of unsecured creditors in bankruptcy, but because in the absence of a functional security system, they cannot prevent a borrower on the verge of failure from liquidating its assets and transferring the proceeds to its owners or related parties (or transferring the collateral directly to these parties). We suspect that the primary reason that lenders in these countries are reluctant to lend is their inability to prevent such fraudulent transfers. Bebchuk \& Fried, supra note 7, at 874 . Second, even if lenders' main concern is not the borrower's misbehavior, but rather their priority position in bankruptcy, the fact that these lenders are reluctant to lend when they have $0 \%$ priority in bankruptcy (i.e., they share pro rata with other unsecured creditors) does not prove that they would be reluctant to lend if they had, say, $80 \%$ priority. Put simply, the behavior of lenders in countries where there is no functional system of security can shed little light on how U.S. lenders would behave if security interests would give them partial priority over the claims of unsecured creditors in bankruptcy and full priority against the claims of all other parties. 


\section{The Aggregate Cost of Credit Under Partial Priority}

We just explained that the adoption of a formal partial priority rule need not reduce the aggregate supply of secured credit in the economy. Let us now consider how a partial priority rule would affect the aggregate cost of credit, assuming, for purposes of the analysis, that the availability of credit remains the same. As we will see, a partial priority rule could either increase or decrease the aggregate cost of credit in the economy.

To begin, let us assume that partial priority has no direct effect on borrowers other than on the distribution of the borrower's assets in bankruptcy, which, in turn, affects the cost of both secured and unsecured credit. ${ }^{156}$ To the extent that a partial priority rule reduces the expected value of secured creditors' share of bankruptcy value, secured creditors will charge more under such a rule than under a rule of full priority. However, voluntary unsecured creditors, in aggregate, should be willing to charge less interest under a partial priority rule than under full priority. ${ }^{157}$ In a world where (1) the priority rule's only effect is to change the distribution of assets in bankruptcy and (2) all of the unsecured creditors are voluntary and set their interest rates to reflect their risk of loss, the total cost of credit should remain unchanged.

Now, let us assume (as we have argued is likely to be the case) that partial priority not only affects the distribution of value in bankruptcy, but also causes borrowers and their secured creditors to enter into more efficient arrangements than under full priority. ${ }^{158}$ In a world where partial priority has these two effects and all unsecured creditors set their interest rates to reflect their expected risk of loss, the total cost of credit will actually be lower than under full priority, because the risk of loss that unsecured and partially secured creditors face will be lower in a world where borrowers and their lenders act more efficiently.

Finally, let us make the assumptions more realistic by assuming that there are many unsecured creditors that are not voluntary and therefore cannot set the interest rate to reflect their expected risk of loss. These creditors will not charge less interest under partial priority than under full priority. Thus, the reduction in interest that unsecured creditors charge will not be as great as in a world where all of the unsecured creditors are voluntary. But the reduction in interest charged by voluntary unsecured creditors might still be greater than the increase in interest charged by secured creditors, in which case the total cost of credit will be lower under partial priority than under full priority. Otherwise, the total cost of credit will be higher under partial priority.

156 Below, we will relax this assumption and examine the case in which partial priority causes borrowers and their lenders to act more efficiently. See infra notes 152-53 and accompanying text.

157 For evidence that lenders take priority rules into account in determining their lending policy, see Klee, supra note 32, at [107].

158 See Bebchuk \& Fried, supra note 7, at 870-71; supra Parts III, IV. 
However, if the total cost of credit is higher under partial priority than under full priority, it is only because involuntary creditors receive more in bankruptcy under partial priority. Presumably, we would prefer that tort and government claims are paid more in bankruptcy, even if this raises the total cost of credit. Put differently, few would argue that we should attempt to reduce the total cost of credit by making it more difficult for tort and government claims to be paid in bankruptcy. ${ }^{159}$

\section{B. The Financing of Good and Bad Projects}

In Section A, we explained why adoption of a partial priority rule need not reduce the availability of secured credit or increase the overall cost of credit. However, the aggregate amount and cost of credit in the economy is not as important as the uses to which the credit is put. If the effect of the availability of low-cost credit is to allow inefficient projects to go forward, while not facilitating the financing of good projects, than the availability of low-cost credit would clearly be undesirable. We now turn to the effect of the priority rule on the financing of different types of projects.

\section{The Question}

Let us now move to the central question: how does partial priority (relative to full priority) affect firms' ability to undertake given projects? From the perspective of economic efficiency, we want firms to undertake all good projects (those that are value-increasing) and undertake no bad projects (those that are value-decreasing). If borrower $F$ and creditor $C 1$ would capture all of the benefits of a project and bear all of the costs, the two would have an incentive to finance and pursue a project if and only if it were value-creating. The problem is that, when there are nonadjusting creditors, borrower $F$ and creditor $C l$ will not necessarily capture all of the benefits and bear all of the costs of a project. Some of the benefits and costs will accrue to nonadjusting creditors (unless there is further renegotiation ${ }^{160}$ ). This can distort the agreement between borrower $F$ and creditor $C 1$ to finance a particular project, as we explain below.

\section{The Effect of Partial Priority on the Financing of Good Projects}

Let us now consider the circumstances under which partial priority would prevent the financing of good projects that full priority would facilitate. Suppose that, under a rule

159 One who believes that tort judgments are too high may favor reducing the payout to tort claims in bankruptcy. See Harris \& Mooney, supra note 11, at [120 n.65]. However, if tort judgments are too high, the solution would not be to distort the entire commercial lending system, but rather to reform the tort system or, perhaps, to subordinate tort claims in bankruptcy to the claims of other unsecured creditors.

160 See infra Part VI.B.4. In principle, an efficient project should always go forward because there are ways to share the gain to make all parties better off. See Robert E. Scott, The Truth About Secured Financing, 82 CORNELL L. REV. [101, 106]; Fried, supra note 8, at [17]. In the real world, however, it is often difficult to reach this result. See Fried, supra note 8, at [7-9]. 
of partial priority, borrower $F$ is considering financing a project with a loan from creditor $C 1$. Suppose that the project would be value-increasing, but that borrower $F$ and creditor $C 1$ cannot capture enough of the gain under partial priority to make it worthwhile for them to pursue the project. Specifically, suppose that the project would generate a surplus of 100 but would confer a positive externality on nonadjusting creditors of 120 (and the nonadjusting creditors are unwilling to reduce the size of their claims in order to reduce the size of the externality ${ }^{161}$ ). Thus, the project would make borrower $F$ and creditor $C I$ worse off by 20 even though it would produce a net surplus of 100 .

Full priority would facilitate such a project if the additional transfer of expected bankruptcy value as a result of the project is at least 20 . Suppose that the additional transfer of expected bankruptcy is 30 . In that case, the project would make nonadjusting creditors better off by only 90 , leaving 10 of surplus available to be shared between borrower $F$ and creditor $C 1$. As a result, the two will have an incentive to pursue the project.

More generally, full priority would facilitate the financing of value-creating projects that would not go forward under partial priority whenever both of the following conditions obtain: (1) under partial priority, the value-creating project will confer a positive externality on nonadjusting creditors that is bigger than the surplus it would create (and the parties are unable to renegotiate to reduce this externality ${ }^{162}$ ) and (2) under full priority, the positive externality is reduced sufficiently so that it becomes smaller than the surplus that would be created.

\section{The Effect of Partial Priority on the Financing of Bad Projects}

Next, consider the circumstances under which partial priority would prevent the financing of bad projects that full priority would facilitate. ${ }^{163}$ Suppose that, under a rule of partial priority, borrower $F$ is considering financing a project with a loan from creditor $C l$. Suppose that the project would be value-decreasing, and that borrower $F$ and creditor C1 would not transfer enough bankruptcy value from nonadjusting creditors to make it worthwhile for them to pursue the project. Specifically, suppose that the project would generate a loss of 100 and would make borrower $F$ and creditor $C 1$ worse off by 20 .

Full priority would facilitate such a project if the additional transfer of expected bankruptcy value is at least 20 . Suppose that the additional transfer of expected bankruptcy is 30 . In that case, the project would make nonadjusting creditors worse off by 110 , leaving 10 available to be shared between borrower $F$ and creditor $C 1$. As a result, the two will have an incentive to pursue the project.

\footnotetext{
161 See infra Part VI.B.4.

162 See infra Part VI.B.4.

163 For a discussion of why secured lenders might find it worthwhile to engage in value-decreasing transactions, see Klee, supra note 32, at [115-16].
} 
More generally, full priority will facilitate the financing of value-decreasing projects that would not go forward under partial priority whenever both of the following conditions occur: (1) under partial priority, the value-reducing project will not transfer sufficient value from nonadjusting creditors to make it worthwhile and (2) under full priority, sufficient value is transferred from nonadjusting creditors so that it makes the project worthwhile.

\section{Assessing the Overall Effect of Partial Priority on Financing}

One cannot determine the overall effect of partial priority on the financing of good and bad projects on a priori theoretical grounds. The net effect may also depend on the extent of the reduction in priority. For example, on the margin, reducing priority from $100 \%$ to $90 \%$ may create a desirable net effect, but moving from $90 \%$ to $80 \%$ may create an undesirable net effect. Therefore, we would need evidence to make the determination as to what level of priority yields the optimal mix of projects. ${ }^{164}$

Even so, there are some general reasons to think that partial priority is not as likely to prevent the financing of value-increasing projects as it is likely to prevent the financing of value-decreasing projects. When an efficient activity would otherwise not take place under partial priority because it would confer too great a benefit on nonadjusting creditors, those creditors may find it in their interest to modify their contractual rights to reduce the size of the positive externality, and permit the activity to take place. That is, when nonadjusting creditors would gain from certain activities that will not be financed under partial priority because the equityholders would capture too little of the activities' benefit, the nonadjusting creditors might agree to reduce their claims (by, for example, forgiving part of their loans) in order to induce the equityholders to undertake the project. The nonadjusting creditors will be better off receiving full payment on their reduced claims than receiving little or no payment on their full claims. Indeed, lenders in workouts commonly agree to reduce the size of their claims, presumably in order to increase the likelihood of eventually receiving payment on the remainder of their claims. ${ }^{165}$

\section{The Effect of Partial Priority on the Financing of Post-Bankruptcy Projects}

A partial rule will affect not only the financing of projects outside of bankruptcy, but also the financing of projects in Chapter 11. Dean Baird has suggested two ways in

164 We commend Harris and Mooney for offering suggestions for the collection of such information, see Harris \& Mooney, supra note 11, at [109-13], as well as the legal commentators and economists who have enriched our understanding of the secured credit through field and econometric studies. See, e.g., Berger \& Udell, supra note 88; Allen N. Berger \& Gregory F. Udell, Relationship Lending and Lines of Credit in Small Firm Finance, 68 J. Bus. 351 (1995); Leeth \& Scott, supra note 96; Mann, Explaining the Pattern, supra note 47; Mann, Small-Business Lending, supra note 47; Mann, supra note 11; Scott, supra note 5 .

165 See Stuart C. Gilson et al., Troubled Debt Restructurings: An Empirical Study of Private Reorganization of Firms in Default, 27 J. FIN. ECON. 315, 318, 322 (1990). 
which a partial priority rule may have detrimental effects in bankruptcy. ${ }^{166}$

The first is that partial priority would simply provide more money for lawyers to spend on reorganization and would therefore waste resources that would otherwise be allocated to more productive uses. ${ }^{167}$ To begin, it is not clear that providing more resources for funding reorganizations would be undesirable. It is possible, as Dean Baird recognizes, ${ }^{168}$ that there are currently insufficient assets to finance the reorganization of businesses that should continue to operate. However, assuming, arguendo, that a partial priority rule would, if inserted into the current bankruptcy system, lead to wasteful attempts at reorganization, one could simply modify bankruptcy rules to ensure that the value transferred from secured creditors is not used to pay administrative expenses. For example, value could be transferred from secured to unsecured creditors (according to the fixed-fraction or any other partial priority rule) only at the very end of the proceeding.

The second point Dean Baird makes is that partial priority may make it more difficult to create the financial structure of the emerging company because some parties will prefer full priority. ${ }^{169}$ However, this argument is the bankruptcy analogue to the argument discussed above, that full priority is necessary to obtain desirable financing outside of bankruptcy. ${ }^{170}$ If partial priority yields a better mix of projects outside of bankruptcy, then it should also yield a better mix of projects in companies emerging from bankruptcy. Of course, if Dean Baird is right that full priority is necessary to achieve the optimal mix of projects in firms coming out of bankruptcy, then this should be true outside of bankruptcy aŝ well.

\section{ON THE ENFORCEMENT OF PARTIAL PRIORITY}

This Part addresses the circumvention objection that has been raised against our partial priority rules--that borrowers and creditors could easily avoid the effect of partial priority in bankruptcy. Two circumvention strategies have been considered. The first is that, regardless of how we implement partial priority, creditors could structure their transactions in a way that would be economically equivalent or similar to a secured loan, but

166 Baird, supra note 44 , at [115-16].

167 See id. at [115]; see also Bossetti \& Kurth, supra note 114, at 28 (noting that proposed revisions expanding Article 9 will reduce the assets available to administer the bankruptcy estate).

168 Baird, supra note 44 , at [116].

169 Id. at [116].

170 See supra Part III.A-B. 
formally would not fall under the partial priority rule. ${ }^{171}$ The second is that secured creditors seizing their collateral outside of, or prior to, the debtor's bankruptcy filing can circumvent a partial priority rule implemented only in bankruptcy. ${ }^{172}$ The analysis of this Part suggests that neither one of these circumvention strategies is likely to materially undermine the effectiveness of a partial priority rule in bankruptcy. Before elaborating however, it is worth pointing out that there is a tension between the argument that creditors can easily circumvent a rule of partial priority and the argument that a rule of partial priority would substantially reduce the financing of good projects.

A. The Tension Between the Circumvention and Credit Availability Arguments against Partial Priority

If one believes that borrowers and creditors can easily circumvent a rule of partial priority, then one cannot simultaneously argue that adoption of such a rule would substantially reduce the availability of financing for good projects. (Of course, if one believes that a creditor could circumvent a formal partial priority rule, but only at some expense, one could object to such a rule on the grounds that such a rule might produce undesirable transaction costs.) Likewise, those who argue that a partial priority rule would reduce the financing available for good projects are implicitly assuming that creditors could not easily circumvent such a rule.

\section{B. Circumvention Through Alternative Forms of Financing}

\section{The Severity of the General Problem}

As symposium participants and others have pointed out, there are many arrangements that accomplish a result similar to a secured loan but which would receive more favorable treatment in bankruptcy under a formal partial priority rule. ${ }^{173}$ Borrowers and creditors facing a rule of partial priority may seek to avoid its effects by using such arrangements. Although there are many ways to accomplish a result similar to a secured loan, all of the arrangements have one thing in common: they put the ownership in the assets that would have served as collateral for a secured loan in the hands of another (perhaps related) party, in an attempt to make those assets unavailable to the borrower's unsecured creditors in bankruptcy.

In our view, the problem of circumvention through the use of economically similar but legally different arrangements would not be as severe as others believe. Application of a rule resembling a partial priority rule to arrangements similar to secured credit, but that

171 See, e.g., Turner, supra note 6, at 331; White, supra note 5, at 502-08.

17 See, e.g., LoPucki, supra note 11, at [111-12].

173 See, e.g., Baird supra note 44, at [105]; Klee, supra note 32, at [109-10]. 
would otherwise remain outside its reach, could substantially reduce circumvention. ${ }^{174}$ In general, courts pay attention to substance over form. For example, if the parties characterize an arrangement as a lease, but it is in fact economically equivalent to a secured loan, a bankruptcy court will treat it as a secured loan.

Thus, two parties that would otherwise have used a secured loan could avoid a partial priority rule only by using an arrangement that is substantially, economically different from a secured loan. However, using an economically different arrangement will often impose costs on the parties that a secured loan would not impose. Parties would bear these whether or not either party enters bankruptcy. In contrast, a partial priority rule will impose costs on the parties only if one of the parties enters bankruptcy. Thus, the expected cost of partial priority would have to be quite high (or the cost of substituting an alternative arrangement would have to be quite low) for the use of alternatives to secured loans to be worthwhile.

We now turn to briefly examine specific types of alternative financing arrangements: (1) the use of leases rather than secured loans; (2) the use of subsidiary financing; and (3) the use of "special purpose" or "bankruptcy-remote" vehicles to isolate liquid assets (typically receivables from creditors in bankruptcy).

\section{The Use of Lease Arrangements}

Under a rule of partial priority secured creditors might consider using leases, which can be functionally similar to secured loans, yet bankruptcy courts will generally not treat them as secured loans. ${ }^{175}$ Under current bankruptcy law, leased assets are not the debtor's property and, therefore, do not enter the bankruptcy estate, ${ }^{176}$ so, in turn, their value is not available for distribution to the creditors. Instead, the bankrupt firm must either cure any existing defaults and then either assume the lease (or assign it to another party) or reject the lease and return the assets to the lessor. ${ }^{177}$ As a result, the lessor is assured of receiving either the assets or the contract for payments after the lessee enters bankruptcy. If a rule of partial priority were in effect, a secured creditor would receive only a portion of the value of the assets serving as collateral for its loan. Thus, firms and their sophisti-

174 For further support for this view, see Klee, supra note 32, at [109-10].

175 See, e.g., White, supra note 5, at 504. In a sale-leaseback transaction, a firm sells assets to another party which then leases them back. A standard lease agreement requires the firm to make periodic payments on the lease to the lessor, and gives the lessor the right to repossess the assets in the event of the firm's default. At the termination of the typical lease, the lessee may either return the assets or purchase them. Depending on its terms, the lease may very closely resemble a secured transaction. In both cases, the firm has use of an asset, agrees to make a stream of payments to another party, and must relinquish possession of the asset if it fails to make these payments.

176 See 11 U.S.C. § 541(b)(2) (1994).

17 See 11 U.S.C. $\$ \S 365(a)-(d)$ (1994). 
cated creditors would have an incentive to structure secured transactions as leases to avoid the effect of a rule of partial priority. But, as we explained, current law makes it somewhat difficult for an arrangement that is like a secured loan to be treated as a lease in bankruptcy. That is, even if the parties label an arrangement a "lease," a bankruptcy court may consider it a secured loan for bankruptcy purposes. ${ }^{178}$ A real economic difference must exist between a lease arrangement and a secured loan for bankruptcy law to recognize the arrangement as a lease. ${ }^{179}$ For a bankruptcy court to treat the arrangement as a lease the arrangement must, for example, not make the lessee bear the cost of depreciation, and it must terminate before the end of the asset's life. ${ }^{180}$

To the extent the lease is functionally different from a secured loan, it is likely to impose costs on the parties that a secured loan would not impose. For example, because the lessee would not bear the risk that the leased assets will fall in value by the end of the lease term, it would have less incentive to properly use and maintain them. The lessor must thus impose restrictions on the assets' use and monitor the lessee's compliance, a costly arrangement for both parties. ${ }^{181}$ If these costs, which the parties would bear whether or not the lessee goes bankrupt, exceed the lessor's expected costs of acting as a secured lender under partial priority, then the parties would not substitute a lease for a secured loan under full priority. ${ }^{182}$

Even if current law permitted leases structured very similarly to secured loans to receive lease treatment in bankruptcy, courts could easily enforce the partial priority rule by modifying the treatment of leases in bankruptcy to conform it to that accorded to secured loans. To the extent leases are similar to secured loans, no economic or other justification exists for treating the arrangements differently in bankruptcy. Thus, there is no reason why lessors could not receive less favorable treatment in bankruptcy than they currently enjoy if

178 See Klee, supra note 32, at [109-10].

179 See U.C.C. § 1-201(37) (1994); White (1983), supra note 5, at 420.

180 See White, supra note 6 , at 420 .

181 See generally Clifford W. Smith, Jr. \& L. MacDonald Wakeman, Determinants of Corporate Leasing Policy, 40 J. FIN. 895 (1985) (discussing incentives that influence the decision to enter a lease).

182 Bossetti \& Kurth, supra note 114, at 17. Other costs exist for the leasing parties. For example, if the marginal tax rate of the lessee is higher than that of the lessor, so that the depreciation is worth more if the lessee owns the property, there will be a tax disadvantage to leasing. See Smith \& Wakeman, supra note 177 , at 897 . Furthermore, the bankruptcy treatment of leases is not entirely favorable. If the debtor decides to breach the lease, any damage claim by the lessor will be treated as an unsecured general claim that arose before bankruptcy. In addition, the bankrupt firm may assign the lease to another party, notwithstanding any anti-assignment provisions in the lease contract. Thus, the lessor may find itself in a contractual relationship into which it otherwise would not have chosen to enter. 
that treatment were necessary to enforce a partial priority rule. ${ }^{183}$

\section{The Use of Subsidiaries}

One way firms might attempt to achieve the effect of full priority under a rule of partial priority is to put in a subsidiary the assets to serve as collateral for a secured loan. ${ }^{184}$ The parents of unsecured creditors cannot reach the assets if the parent goes bankrupt, because, in principle, their claims would have no more priority in the assets of the subsidiary than the claims of the parent, the subsidiary's shareholder. The creditor whose loan the subsidiary's assets secured would thus effectively have full priority in the assets.

There are a number of reasons why this strategy is unlikely to substantially undermine a partial priority rule in bankruptcy. First, the creation of a subsidiary and the maintenance of corporate formalities involves costs which are borne whether or not either the subsidiary or the parent goes bankrupt. These costs, in turn, would discourage many (but not all) firms from pursuing this approach. Second, this strategy is not without risk. In particular, the subsidiary's activities (including, perhaps, the ownership and lease or operation of the assets transferred to it by the parent) may give rise to unsecured claims against it-government claims, tort claims, or even trade claims-that erode the priority of the secured creditor whose loan is secured by the subsidiary's assets. These unsecured claims will also have full priority over any unsecured claims against the parent. Thus, to the extent the parent itself borrows from sophisticated unsecured creditors, the parent will pay a higher interest rate on these loans. Third, if it turns out that creditors widely use this strategy and effectively undermine the partial priority rule in bankruptcy, bankruptcy courts could consolidate the assets of, and claims against, subsidiaries and parents to render the

183 Indeed, according the lessor less favorable treatment in bankruptcy-such as by allowing the bankruptcy estate to reduce their payment obligations under lease contracts-should yield efficiency benefits. As we pointed out in The Uneasy Case, to the extent leases and secured loans are substitutes, leases are likely to give rise to the same type of efficiency problems this Article identifies. Bebchuk \& Fried, supra note 7, at 926-29. In fact, covenants that public companies issue typically place similar restrictions on borrowers with respect to both security interests and leases. See Morey W. McDaniel, Are Negative Pledge Clauses in Public Debt Issues Obsolete, 38 Bus. LAW. 867, 868 (1983). Indeed, the only restrictions found in the debentures of companies rated A or better are sale-leaseback restrictions and negative pledge covenants, see id., suggesting that the two arrangements have similarly undesirable efficiency consequences. Thus, even in a world without secured lending, there might be efficiency benefits to giving lessors less favorable treatment in bankruptcy than they currently enjoy. For example, giving less favorable treatment may reduce the use of inefficient lease arrangements which are used to give the lessor a better position in bankruptcy. Another possible benefit is that it might reduce the problem of inefficient rejection of leases. See Fried, supra note 140, at 545-66 (explaining how adjusting the price of an executory contract against the nonbankrupt party can reduce the problem of excessive rejection in bankruptcy).

184 See Bossetti \& Kurth, supra note 114, at 16; LoPucki, supra note 103, at 20-21. 
strategy ineffective. ${ }^{185}$

\section{4. "Special Purpose" or "Bankruptcy Remote" Vehicles}

An increasing number of firms, most of them large publicly traded companies, have created so-called "special purpose vehicles" ("SPVs"), also known as "bankruptcy-remote vehicles." 186 An SPV is a separate legal entity, typically a trust, that purchases the borrower's receivables with funds borrowed from public or private investors. The flow of income from the receivables repays the investors. If the firm fails, the SPV, an independent entity, is unlikely to be forced into the proceeding (where, because of the de facto partial priority system, the receivables backing the SPV's obligations to its creditors could be compromised). If secured creditors were to be given even less priority in bankruptcy, then SPVs would become even more attractive.

Nevertheless, the possibility of using SPVs is unlikely to undermine a partial priority rule in bankruptcy. First, although, in principle, firms could use SPVs to shelter operating assets, ${ }^{187}$ at present, firms use SPVs only to isolate non-operating assets, such as receivables. ${ }^{188}$ Second, it is expensive to set up an SPV. Steven Schwarcz estimates that a publicly-traded SPV must issue at least $\$ 50$ million because of the high transaction costs, effectively making this means of financing unavailable to small- and medium-sized companies, the primary issuers of secured debt. ${ }^{189}$ Third, SPVs may reduce, but do not

185 Consolidation is still the exception rather than the rule. See id. at 22. However, given bankruptcy judges' sympathy for unsecured creditors and their considerable discretion, they might become less reluctant to consolidate if they came to believe that debtors were establishing subsidiaries primarily to avoid their liability to unsecured creditors.

186 See generally Claire A. Hill, Securitization: A Low-Cost Sweetener for Lemons, 74 WASH. U. L.Q. $1061,1062,1076$ (discussing the costs and benefits of securitization); LoPucki, supra note 103, at 23-26 (explaining the nature and use of SPVs).

187 See LoPucki, supra note 103, at 25.

188 When receivables capitalize the SPV, the arrangement is equivalent to factoring. See Paul M. Shupack, On Boundaries and Definitions: A Commentary on Dean Baird, 80 VA. L. REv. 2273, 2291 (1994). When the SPV is capitalized with operating assets that the corporation must use, the arrangement will involve a lease of those assets to the corporation, with all of the risks and problems that entails. See supra Part VII.B.2.

189 Steven L. Schwarcz, The Alchency of Asset Securitization, 1 STAN. J.L., Bus. \& Fin. 133, 138-39 (1994). In a conversation with one of the authors, Schwarcz reported that an SPV structure can be created for deals as small as $\$ 5$ million (and perhaps less) if the funding is through bank debt or private placement. While the use of private debt would lower the costs of creating an SPV, many small and medium-sized companies will still not have a sufficient amount of receivables to make an SPV worthwhile. Cf. Berger \& Udell, supra note 158, at 356-61 (reporting that half of 3400 small businesses (including businesses with as much as $\$ 219$ million in assets) surveyed in $1988-89$ by the Federal Reserve Board and the Small Business Administration had assets of $\$ 500,000$ or less). 
eliminate, the risk of bankruptcy. As Steven Schwarcz observes, risk-averse investors are unwilling to lend funds to SPVs whose originating companies are at risk of bankruptcy, indicating that there is still a material risk that SPV investors will be drawn into a bankruptcy proceeding should the parent file for bankruptcy. ${ }^{190}$

\section{Liquidation of Collateral Outside of Bankruptcy}

Secured creditors might try to circumvent partial priority in bankruptcy by seizing collateral outside of bankruptcy in two ways. The first is to ensure that the borrower never enters bankruptcy, but rather liquidates outside of bankruptcy. The second is to seize the collateral before the borrower enters bankruptcy.

\section{Firms That Liquidate Outside of Bankruptcy}

Suppose that the secured creditor believes (correctly) that a defaulting borrower has nothing to gain from entering bankruptcy, and various transaction costs and information problems prevent unsecured creditors from filing an involuntary bankruptcy petition. In such a case, the secured creditor might repossess the collateral while the borrower liquidates its business outside of bankruptcy, escaping the effect of a partial priority rule in bankruptcy.

To eliminate this problem, the law could require that all liquidating companies report all of their transactions within the previous year and submit a list of unsecured creditors to a bankruptcy clearinghouse. The clearinghouse would pass the information on to creditors and "bounty hunters" who would receive a percentage of the assets recovered from the secured creditor. ${ }^{191}$ To enforce the mandatory bankruptcy filing requirement, the government could condition limited liability for the firm's owners on such a filing. ${ }^{192}$

However, even if the law did not change to make these types of liquidations more difficult or impossible, liquidations outside of bankruptcy that give secured creditors full priority in their collateral and leave unsecured creditors' claims unpaid are unlikely to significantly reduce a partial priority rule's effectiveness. First, cases in which neither unsecured creditors nor the borrower has anything to gain from bankruptcy are likely to involve small amounts of assets and claims. More importantly, when a secured creditor extends credit, it will not know if it can avoid being subject to a partial priority rule in bankruptcy. Thus, in negotiating its loan contract with a borrower, it will act as if there is some possibility that

190 Schwarcz, supra note 185 , at 137.

191 There are other possibilities. See LoPucki, supra note 11, at [123-25].

192 In his symposium article, LoPucki suggests that implementing a mandatory bankruptcy filing requirement would require specifying the circumstances under which criminal liability (for failure to file) is imposed (and helpfully offers such a standard). Id. at [125]. But we doubt that criminal enforcement would be necessary if, as we suggest, owners (or, if appropriate, executives) of a borrower that has not yet filed for bankruptcy are held liable for the borrower's debts by the borrower's creditors. In such a case, those controlling the borrower would have an incentive to file for bankruptcy as soon as they believed that the borrower had become insolvent. 
it will lose some of its priority in bankruptcy. ${ }^{193}$

\section{Firms That Give Secured Creditors Their Collateral Prior to Bankruptcy}

The secured creditor may expect that the borrower or unsecured creditors (which would have an interest, under a partial priority rule in bankruptcy, to see the borrower enter bankruptcy) would eventually file a bankruptcy petition. As we explain below , the secured creditor's ability to "opt out" of partial priority by seizing its collateral before bankruptcy would likely be very limited.

Consider first a debtor that intends to resist repossession. The secured creditor would be unable to repossess unless the contract gives it the right to declare a default and seize the collateral. Even if the creditor has the right to declare a default under the loan contract, its ability to seize the collateral will usually be very restricted. In particular, the secured creditor may not seize the collateral if, by doing so, it would breach the peace. ${ }^{194}$ Since most commercial collateral is located on the borrower's property and is thus difficult

193 In his symposium article, Lopucki argues that a secured creditor would attempt to avoid the reach of a partial priority rule in bankruptcy by including provisions in the loan arrangement that give the debtor an incentive to participate voluntarily in an out-of-bankruptcy liquidation that benefits the secured creditor. Id. at [117-18]. In particular, a secured creditor might demand that the owners personally guarantee the debtor's obligation to the secured creditor. Such a guarantee would give the owners an incentive to maximize the secured creditors' recovery in the event of the debtor's failure.

While personal guarantees might be used as part of a strategy to avoid partial priority in bankruptcy, their use would achieve directly one of the results that partial priority is intended to achieve indirectly: namely, to reduce the debtor's incentive to engage in excessively risky activities. Id. at [118]. The guarantee does this by better aligning the owner's incentives with those of creditors generally. In effect, a personal guarantee is equivalent to a partial waiver of limited liability. Because limited liability is what gives rise to inefficient borrower behavior in the first instance, see Bebchuk \& Fried, supra note 7, at 873-75, a partial waiver of limited liability is likely to be desirable. See Mann, Small-Business Lending, supra note 47 , at [25].

LoPucki suggests that the secured creditor might also negotiate for provisions that enable the secured creditor to assume control of the debtor should it suffer financial distress. LoPucki, supra, at [117-18]. We suspect that in many cases these provisions will not be effective. First, lender liability law and the possibility of equitable subordination in bankruptcy might deter a secured creditor from attempting to take control of a debtor and liquidating its assets. Second, in those cases where a secured creditor nevertheless attempts to take control of the debtor in order to liquidate it-and the owners did not personally guarantee the debtor's loans-the owners would have an incentive to resist the takeover by filing for bankruptcy.

However, to the extent such arrangements are effective, they would increase the potential cost of financial distress to the owners of the debtor by putting their ownership and control at greater risk. This, in turn, would reduce owners' incentives to engage in undesirably risky activities. Therefore, such arrangements (if effective) would have the same desirable ex ante effects on the debtors as personal guarantees from the owners, albeit to a lesser degree because, unlike personal guarantees, such arrangements would not expose all of the owner's wealth to risk of loss.

194 See U.C.C. § 9-503 (1994). 
to access without the borrower's cooperation, this breach-of-the-peace restriction makes it virtually impossible for secured creditors to engage in "self-help" repossession. As a result, the secured creditor would almost always need to enlist the judicial system's help in recovering the collateral, providing the borrower with ample time to file for bankruptcy and invoke the automatic stay.

Next, consider a debtor that would not resist, and may even assist in, repossession. ${ }^{195}$ Under a rule of partial priority, a repossession (within a statutorily defined period, usually 90 days) would violate the preference rules (Section 547 of the Bankruptcy Code) by enabling the repossessing secured creditor to obtain more than it would in bankruptcy. Section 547 would thus permit the bankruptcy trustee to undo such a transfer. Thus, the secured creditor's repossession might cause sophisticated unsecured creditors to force the borrower into bankruptcy before the preference period had expired so that the collateral could be recovered and its value could, at least in part, be used to satisfy their claims. ${ }^{196}$ In fact, under current law, unsecured creditors often force a firm into bankruptcy after the firm grants a security interest to another creditor, so that they can attack the transfer of the security interest under Section $547,{ }^{197}$ even though the law makes it both difficult and risky for unsecured creditors to initiate involuntary bankruptcy filings. ${ }^{198}$ Thus, even if a secured creditor could physically repossess its collateral, it might be reluctant to incur the cost of repossession, knowing that unsecured creditors would be likely to simply undo the

195 See LoPucki, supra note 11, at [117-18].

196 In his symposium article, LoPucki describes a strategy secured creditors could, in principle, use to defeat the preference rules: a single-purpose entity is created to lend money to, and take a security interest in, the property of a borrower. Should the borrower default, the entity seizes the collateral, sells it at foreclosure for a fraction of its value to a related party, and then distributes the proceeds of the sale to the owners of the entity, leaving the entity an empty shell. See id. at [126-29]. However, we think that this strategy would not be used on any significant scale. First, the transfer of the proceeds to the owners as well as the transfer of the collateral to a related party for less than reasonably equivalent value would be considered fraudulent transfers that could, in principle, be reversed by the bankruptcy trustee. To the extent that lenders believe that the trustee will simply undo the transfers, they will have no incentive to engage in this strategy. Even if the bankruptcy trustee could not undo the transfers, many lenders would not engage in such transactions for fear of adverse publicity. And those which were not deterred by the possibility of negative publicity might not find it worthwhile to create a separate legal entity for each loan transaction (because the transaction costs would be incurred not only in those cases where there is a foreclosure, but in the overwhelming majority of cases where the borrower fully repays the loan). To the extent that there would still be lenders which would otherwise use such vehicles, stiffer penalties could be imposed on those receiving the proceeds or otherwise profiting from the transactions.

197 See LoPucki, supra note 58, at 1927 (finding that, in a sample of large companies that declared bankruptcy, unsecured creditors filed involuntary bankruptcy petitions when the borrower issued a security interest to existing lenders which originally made their advances on an unsecured basis).

198 See LoPucki, supra note 11 , at [111-12, 119-20]. 
repossession by filing a bankruptcy petition and attacking the transfer under Section 547. ${ }^{199}$

\section{A NOTE ON THE CURRENT CONTROVERSIES OVER ARTICLE 9}

This Part briefly remarks on how our analysis relates to some of the issues raised at the Symposium regarding the current revision of Article 9. The American Law Institute (ALI) and the National Conference of Commissioners on Uniform State Laws (NCCUSL) are now in the process of revising UCC Article 9, the body of rules that permits a lender to take security interests in virtually all of a borrower's personal (moveable or intangible) property. Most of the revisions the ALI and the NCCUSL are considering tend to further strengthen the position of secured creditors: they either extend the reach of Article 9 to property currently uncovered (including certain bank deposits, tort claims, and insurance claims) or make it easier for secured creditors to achieve priority in their Article 9 collateral over the claims of third parties, such as unsecured creditors or the borrower's bankruptcy trustee. ${ }^{200}$ In part, these revisions are intended to reverse some of the erosion of priority that has resulted from courts interpreting Article 9 against secured creditors. ${ }^{201}$

However, a revision proposed by Elizabeth Warren goes in the exact opposite direction: it would "carve out" a portion of a debtor's Article 9 collateral to pay the claims

199 LoPucki argues that unsecured creditors are unlikely to file many involuntary petitions if a partial priority rule is adopted. Id. at [120-21]. One reason is that under current bankruptcy rules parties filing involuntary petitions face significant risk of liability. See id. at [119-20]. The other reason is that there would be little benefit to the unsecured creditor filing the petition. Any value that is made available by a partial priority rule in the bankruptcy proceeding may be used to pay administrative expenses. Whatever is left must then be shared pro rata with other ordinary unsecured creditors. See id. at [120]. LoPucki suggests that an unsecured creditor would thus be better off bargaining with the secured creditor for a side-payment in exchange for not filing a bankruptcy petition. Id. at [120-23].

LoPucki might be right that, if other bankruptcy rules are not changed, unsecured creditors would generally prefer to extract a side-payment rather than file for bankruptcy. But we should emphasize two points: the first is that such side-payments will have the effect of giving the secured creditor only partial priority in its collateral (although the degree of priority will be greater than if the secured creditor were brought into the bankruptcy proceeding). Second, bankruptcy rules could be changed to eliminate the disincentives and increase the incentives to file involuntary petitions. LoPucki himself offers one proposal for increasing the incentives to file involuntary petitions: giving a bounty to the filing creditor. LoPucki is concerned that such a system would not be effective in the case where the irreversible nonbankruptcy liquidation takes place before the petitioning creditors are eligible to file. Id. at [123-24]. However, the preference period could be extended from 90 days to 1 year, making most nonbankruptcy liquidations reversible.

200 See Klee, supra note 32, at [101 n.2].

201 See Woodward, supra note 13 , at [110 n.45]. 
of the debtor's unsecured creditors. ${ }^{202}$ Under Warren's so-called "Carve-out Proposal," as much as $20 \%$ of the debtor's Article 9 collateral would be made available to pay the claims of "judgment creditors" - unsecured creditors with unpaid judgments against the debtor-that have levied on that collateral. ${ }^{203}$

\section{A. The Effort to Expand the Scope of Article 9}

Let us first consider the efforts to expand the scope of Article 9 and reduce the transaction costs associated with personal-property secured lending. Expanding the scope of Article 9 may or may not be desirable from an efficiency perspective. Suppose that the proposed expansion of Article 9 would enable creditors to take security interests in certain types of assets that, until now, could not be used as collateral (under Article 9 or otherwise). When used, these security interests would give rise to priority-independent costs and benefits and priority-dependent costs and benefits. The use of such security interests might also affect the mix of good and bad projects that are financed. The desirability of enabling creditors to create such security interests would depend on whether the benefits exceed the costs.

Because the priority-dependent costs and benefits of these security interests depend on the degree of priority accorded to secured claims in bankruptcy, the overall desirability of expanding the scope of Article 9 might depend on whether there is full or partial priority in bankruptcy. (And the desirability of full or partial priority might depend on the types of assets that can serve as collateral for a security interest.) Otherwise, the issues of priority and the scope of Article 9 are independent. There are two separate questions: (1) should it be possible to create an Article 9 security interest in all types of personal property assets and (2) should security interests have partial priority in bankruptcy? Even if one believes that it would be preferable to give less priority to secured claims in bankruptcy than they enjoy currently, one can also believe that it would be desirable to enable creditors to take security interests in all personal-property assets (even if the priority regime remains the same). Similarly, one may believe that it is optimal to give full priority to security interests in certain types of assets, while, at the same time, believing that certain types of assets should not be permitted to serve as collateral under any regime of priority.

The net effect of reducing the transaction costs associated with Article 9 lending could also be either positive or negative. Consider Article 9 security interests that firms would use in any event. With respect to these security interests, it is clearly desirable to reduce the transaction costs associated with their use. Now consider Article 9 security interests that firms would use only if the transaction costs associated with their use were reduced by the proposed rationalization of Article 9 . With respect to these security interests, a reduction in transaction costs could have either positive or negative efficiency effects, depending on whether the resulting increase in the use of Article 9 security interests is

202 Warren, supra note 12.

203 See id. 
desirable. The use of these security interests would be desirable to the extent that they add value to transactions, but undesirable to the extent that they make the transaction less efficient. Similarly, to the extent the reduction in transaction costs permits financing of good projects, this would be desirable; likewise, to the extent such a reduction gives rise to loans for bad projects, the effect would be undesirable.

\section{B. The "Carve-Out" Proposal}

Contributors to this Symposium and others have discussed the details and design of the "carve-out" proposal. ${ }^{204}$ Here, we will simply make some brief general points about an Article 9 collateral carve-out rule.

An Article 9 carve-out rule would differ from the partial priority rules we consider in three important respects. First, the carve-out applies only to personal property, while the partial priority rules we put forward apply both to personal and real property. ${ }^{205}$ Second, the carve-out rule "carves out" a portion of a secured creditor's collateral for unsecured claims, while the partial priority rules "carve out" a portion of the secured creditor's secured claim and make it unsecured. The difference is as follows: under the carve-out rule, a secured lender could completely insulate itself from risk of loss by oversecuring its loan. Under our partial priority rules, a lender could not, because its secured claim would be subject to a cut-back. Third, the carve-out rule applies both in and outside of bankruptcy; our partial priority rules apply only in bankruptcy.

The first difference between our partial priority rules and the carve-out rule is that the carve-out rule would apply only to Article 9 personal-property collateral. ${ }^{206}$ Personal property accounts for only a fraction of the collateral backing secured debt in the United States, perhaps as little as $10 \% .{ }^{207}$ A $20 \%$ carve-out rule might thus carve out as little as

204 See, e.g., Bossetti \& Kurth, supra note 114; Klee, supra note 32; Woodward, supra note 13, at [101-02].

205 Many of the partial priority rules that other countries have considered or adopted apply only to personal property (or specific types of personal property). See Eisenberg \& Sundgren, supra note 38 (discussing bankruptcy laws in Finland); supra note 29 (discussing 1985 German Bankruptcy Commission Proposal). In 1982, the U.K.'s Cork Commission proposed a more limited version of the fixed-fraction priority rule under which $10 \%$ of the property subject to floating charges (such as inventory) would be made available to pay unsecured claims. See Goode, supra note 43, at 66-67.

206 Much of the scholarship cited supra note 5 has implicitly or explicitly focused on security interests in personal property. However, the analysis we and many others have offered applies to both personal and real property. For articles that focus exclusively on real property security interests, see Johnson, supra note 5; Mann, supra note 11.

${ }^{207}$ See Picker, supra note 5, at 649-50 (estimating real property mortgage debt at $\$ 3.85$ trillion, automobile-backed debt at $\$ 285$ billion, and $\$ 96$ billion of other debt, secured primarily by personal property). These figures presumably include both commercial and non-commercial loans. Thus the 
$2 \%$ of total business collateral for unsecured creditors. The benefits (and costs) of an Article 9 carve-out rule would thus be lower than the benefits of a partial priority rule that applies to both real and personal property security interests.

The second difference is that the carve-out rule applies to collateral, while the partial priority rules apply to claims. As explained above, under the carve-out rule, a secured creditor could insulate itself from risk of loss by oversecuring the loan (taking collateral worth at least $125 \%$ of the amount it expects to be owed in the event of default). Thus, even if the carve-out rule applied both to personal and real property, one would expect it to lead to less monitoring of borrowers than a rule such as the fixed-fraction rule, which always exposes a secured lender to risk of loss.

Third, the carve-out rule would operate both inside and outside of bankruptcy, while our rules would operate only in bankruptcy. The carve-out rule would have the advantage of reaching a larger number of insolvent companies. ${ }^{208}$ The problem is that it would also apply to solvent companies, creating potential costs without generating any offsetting benefits.

\section{CONCLUSION}

This paper has responded to criticisms of The Uneasy Case and further developed the analysis of that paper. The analysis confirms our earlier conclusion that the case for full priority of secured claims in bankruptcy is an uneasy one. The contributions to this Symposium, and the discussion during its sessions, suggest to us that many others are coming around to accept this view.

In closing, however, we wish to caution against rushing to conclude that a partial priority rule would be superior to full priority. Much more work needs to be done before one can determine with confidence which rule would be desirable. We hope that our papers can provide a useful basis and agenda for such future work.

percentage of commercial secured debt that Article 9 collateral backs could be more or less than $10 \%$. See Mann, supra note 11 , at 12 n.4.

${ }^{208}$ See supra Part VII.B. 